IZA DP No. 10193

The Changing Occupational Distribution by

College Major

Michael R. Ransom

Aaron Phipps

September 2016 


\title{
The Changing Occupational Distribution by College Major
}

\author{
Michael R. Ransom \\ Brigham Young University \\ and IZA
}

Aaron Phipps

University of Virginia

\section{Discussion Paper No. 10193 \\ September 2016}

\author{
IZA \\ P.O. Box 7240 \\ 53072 Bonn \\ Germany \\ Phone: +49-228-3894-0 \\ Fax: +49-228-3894-180 \\ E-mail: iza@iza.org
}

Any opinions expressed here are those of the author(s) and not those of IZA. Research published in this series may include views on policy, but the institute itself takes no institutional policy positions. The IZA research network is committed to the IZA Guiding Principles of Research Integrity.

The Institute for the Study of Labor (IZA) in Bonn is a local and virtual international research center and a place of communication between science, politics and business. IZA is an independent nonprofit organization supported by Deutsche Post Foundation. The center is associated with the University of Bonn and offers a stimulating research environment through its international network, workshops and conferences, data service, project support, research visits and doctoral program. IZA engages in (i) original and internationally competitive research in all fields of labor economics, (ii) development of policy concepts, and (iii) dissemination of research results and concepts to the interested public.

IZA Discussion Papers often represent preliminary work and are circulated to encourage discussion. Citation of such a paper should account for its provisional character. A revised version may be available directly from the author. 
IZA Discussion Paper No. 10193

September 2016

\section{ABSTRACT}

\section{The Changing Occupational Distribution by College Major}

In this paper we examine the occupational distribution of individuals who hold bachelor degrees in particular fields in the United States using data from the various waves of the National Survey of College Graduates. We propose and calculate indexes that describe two related aspects of the occupational distribution by major field of study: distinctiveness (how dissimilar are the occupations of a particular major when compared with all other majors) and variety (how varied are the occupations among those who hold that particular major). We discuss theoretical properties of these indices and statistical properties of their estimates. We show that the occupational variety has increased since 1993 for most major fields of study, particularly between the 1993 and 2003 waves of the survey. We explore reasons for this broadening of the occupation distribution. We find that this has not led to an increase in reported mismatch between degree and occupation.

JEL Classification: $\quad 123, \mathrm{~J} 24$

Keywords: college major, occupation

Corresponding author:

Michael Ransom

Department of Economics

143 FOB

Brigham Young University

Provo, UT 84602

USA

E-mail: ransom@byu.edu

\footnotetext{
${ }^{*}$ We thank Evan Magnusson for helpful research assistance and Jessica Ransom McDowell for editorial advice.
} 


\section{Introduction}

Different college degree programs train individuals for the labor market in distinct ways. Some fields of study are professionally or vocationally oriented, preparing individuals for rather specific occupations-examples are the engineering fields, accounting and nursing. Other undergraduate courses follow the tradition of a liberal arts education, in which the guiding principle is to teach people to think and write well, with little concern for what sort of work a student might do upon graduation.

The choice of college degree is influenced by desired occupation, but college degree also influences occupational choice. Research has shown that the choice of college major is responsive to the relative pay of graduates with those majors, as in Arcidiacono (2004), or Montmarquette, Canning and Majseredjian (2002), or the relative pay of occupations related to those majors, as in Long, Goldhaber and Huntington-Klein (2014). Similarly, Freeman and Hirsch (2008) show that the number of students that graduate with a particular college major is responsive to the knowledge content of occupations and the market payoff to that knowledge content. Choice of occupation is also likely influenced by knowledge and skills that are learned in a course of study. For example, Yamaguchi (2010) finds evidence that college graduates know more about suitable careers than those who do not attend college, so there is less careerchanging among college graduates than among high school graduates.

In fact, the process of obtaining a degree in a specific field is much more complex than simply choosing a major. Altonji, Blom and Meghir (2012) and Altonji, Arcidiacono and Maurel (2015) develop models of major choice that incorporate preferences and innate ability, but also stress that students learn about their preferences and ability as they proceed in an 
educational program.

Although students may choose a college major with a particular occupation in mind, most college majors do not prepare students for particular occupations, and even for those degrees that are most occupationally oriented, there is a distribution of chosen occupations. In this paper, we examine the occupational distribution of individuals who hold college degrees in various major fields. We quantify the occupational distribution using two indices. The first is the well-known dissimilarity index, which measures the distinctiveness of occupations held by graduates with a particular major when compared to the occupations of all other majors. In our context we refer to this as occupational distinctiveness index (OD). Essentially, the distinctiveness index measures the occupational segregation of majors in the labor market. The second is an index that measures the variety of occupations held by individuals whose undergraduate degree was in a specific field, which we refer to as occupational variety (OV). On one end of the spectrum are degree fields whose graduates all have the same occupation, or nearly so. On the other end are degree fields which are represented among a wide variety of occupations.

The paper is organized as follows: Section II introduces the two indexes and discusses their properties. Section III gives an overview of the data from the National Survey of College Graduates. Section IV reports estimates of the indexes, and Section V documents the increase in occupational variety over the period from 1993 to 2010. Section VI discusses some possible reasons for this increase. Section VII summarizes.

\section{Aspects of the Occupational Distribution of College Majors}

To motivate our analysis of occupational distribution, consider Figure 1 which compares the distribution of occupations of economics majors and electrical engineering majors from the 
2003 wave of the National Survey of College Graduates using 22 highly aggregated occupational groups. (We have chosen these two majors simply as an example of two majors that have rather different occupational distributions.) Economics majors appear in all of these broad occupational categories. However, they are highly concentrated in fields related to business, particularly sales and management, which together represent over 50 percent of all jobs held by economics graduates. Economics is also a relatively popular major for judges and lawyers, and (naturally) for economists. The occupational distribution of electrical engineering majors is much more concentrated, with more than half in the engineering field, although computer related occupations, managers and, sales/marketing also are fairly common. Clearly, the distributions are different, although there are areas of significant overlap. In order to characterize the job distributions of college graduates who hold a particular major, we use two indexes that are familiar to economists.

\section{II.1. Distinctiveness}

Our first index measures the degree to which the occupations of those in a particular major are segregated from the occupations of those holding other majors. We refer to this concept as "occupational distinctiveness," and we define this as

$$
O D_{j}=\sum_{i=0}^{K}\left|s_{i j}-s_{i, n o t}\right|,
$$

where $\mathrm{s}_{\mathrm{ij}}$ is the fraction of those who have a major field $\mathrm{j}$ in occupation $\mathrm{i}$, and $\mathrm{s}_{\mathrm{i}}$, not $\mathrm{j}$ is the fraction of those in all other majors who hold occupation i. This index is frequently used in economics and sociology to measure, for example, the level of occupational segregation between the sexes, or between different racial groups, as in Albeda (1986) or Ransom (1990). The index in those situations is called the dissimilarity index. 
In order to make clear what we mean by distinctiveness, it is useful to refer to a graphic representation called the segregation curve. Figure 2 shows segregation curves for three different hypothetical majors, A, B, and C. In this example, there are also three possible occupations. The curve is piecewise linear, with a segment for each occupation. The slope of each segment is the ratio $s_{\mathrm{i}, n o t} / s_{\mathrm{i}, \mathrm{j}}$. The segments are ordered according to their slope, with those with lower ratio plotted first. The segments are connected so that a point on the curve shows the cumulative fraction of those not holding a major compared to the cumulative fraction holding the major. For example, the solid (green) curve shows that in its most distinctive occupation, 40 percent of those with major A are employed in the occupation, while only 4 percent of other majors are in the occupation. The slope of the first segment of curve A is thus, $.04 / .40=0.1$. Restated slightly, those with major A are 10 times more likely than others to work in that occupation. The next segment of the curve is somewhat steeper, indicating that the fraction of those with major A holding that occupation is more similar to the fraction not holding A, while the last segment is very steep, indicating that those with major A are much less likely than other college graduates to be working in that occupation. Because of the segments of the curve are ordered by the slope of the segments, the curve will always be concave.

If the occupational distribution of a major exactly matched the occupational distribution of those not holding the major, then the segregation curve would be the diagonal line—no distinctiveness. If all those holding major A had a particular occupation, and none of those not holding major A had that occupation, then the segregation curve would be the bottom and right edges of the box-perfect distinctiveness.

Curves B and C demonstrate other hypothetical majors. Each line segment on these curves represents an occupation, but the ordering of the occupations is specific to the particular 
major. It is clear that major A is more occupationally distinctive than either B or C, since curve A is below curves B and C everywhere. However, it is not clear how to rank B and C, since the two curves intersect. B is more distinctive in its first occupation and $\mathrm{C}$ is more distinctive in its third occupation.

A numerical index implicitly makes certain value judgements in order to rank all possible distributions. In terms of the segregation curve, our distinctiveness index, OD, is the maximum distance between the curve and the diagonal line. (For major A in Figure 2, this is the length of the line segment xy.) Thus, OD summarizes the level of distinctiveness of a particular major by the maximum deviation of the segregation curve from "equality." One attractive feature of OD is that it can be interpreted as the minimum fraction of those holding a particular major that would have to change occupations in order to achieve the same occupational distribution as all other majors.

Hutchens (1991) and Hutchens (2004) suggest some essential properties for indexes of segregation, which are applicable in this situation. ${ }^{1}$ These are:

D1. Scale invariance. An index is scale invariant if the index does not change when the number of people holding a major is changed without changing the proportions in each occupation.

D2. Symmetry: An index obeys symmetry if exchanging the two groups (in our case, switching those in major A with those not in major A) does not affect the index value.

\footnotetext{
${ }^{1}$ Hutchens (1991) discusses in detail these properties and their application to the dissimilarity index.
} 
D3. Equilibrating transfers: Within a major, moving a person from an occupation where $\mathrm{S}_{\mathrm{i}, \text { not } \mathrm{j}} / \mathrm{s}_{\mathrm{i}, \mathrm{j}}$ is high to an occupation where $\mathrm{s}_{\mathrm{i}, \mathrm{not} \mathrm{j}} / \mathrm{s}_{\mathrm{i}, \mathrm{j}}$ is low (or vice versa) will reduce measured distinctiveness.

D4. Proportional division: Splitting occupations groups into narrower occupations will not alter the index if the proportions in the groups of majors and non-majors is the same as it was in the original occupational groups.

Using the graphical definition presented in Figure 2, it is easy to prove that OD satisfies properties D1, D2, and D4, but not D3. Property D3 fails because the index is insensitive to some types of equilibrating transfers. In the example in Figure 2, transfers between occupations represented by the line segments to the left of point y will not affect OD since the cumulative shares of the two occupations groups do not change. The index will decrease (increase) only when individuals are moved from occupations on the left (right) of y to occupations on the right (left) of y. Another way to interpret this is that OD will change only by transfers from occupations where $\mathrm{s}_{\mathrm{i}, \text { not }} / \mathrm{s}_{\mathrm{i}, \mathrm{j}}$ is greater than 1 to occupations where it is less than 1 , or vice versa. While the insensitivity to equilibrating transfers is an undesirable property, the simple interpretation of the dissimilarity index has led to its almost universal adoption as a measure of segregation. That is, users have generally considered the simplicity of interpretation to outweigh the shortcomings of the index.

From the above discussion, and from the graphical representation of the index, the following properties are obvious:

1. The value of OD depends on the definition of majors and occupational groups which are inherently ad hoc, so care must be taken when comparing the index across time or 
across different populations. If the definitions of majors or occupations differ, the indexes are not comparable.

2. If it is possible to rank distinctiveness by comparing segregation curves, OD will preserve this ranking (since OD is a maximum difference).

3. Changes in the size of a major do not affect the index. Thus, it is possible to compare changes over time even if a particular major increases or decreases in popularity.

4. Aggregation of occupational groups (say comparing a 2-digit versus 3-digit level of aggregation) will never increase the distinctiveness of a major and will almost always reduce it.

5. Broadening the definition of a major has an uncertain impact on the segregation index, depending on the occupational distributions within the majors that are combined. Generally, we would expect that measures of distinctiveness will fall when combining majors into more aggregated levels. However, because changing the definition of a major also changes the definition of who does not have that major, this intuition need not hold.

Furthermore, the index in this case is based upon a sample, and is thus, strictly speaking, a statistic. The sampling distribution of the index is discussed in Ransom (2000). He derives an estimator for the sampling variance, which we estimate and report for our samples.

\section{II.2. Variety}

Another related aspect of the occupational distribution is its variety. In other words, how widely distributed across the occupational distribution are graduates with particular majors? Variety is closely related to concentration. (In fact, for our proposed measure, variety is the 
inverse of concentration, so there is a one-to-one relationship between the concepts.) A popular measure of concentration is the Herfindahl index,

$$
H_{j}=\sum_{i=1}^{K} s_{i j}^{2}
$$

where $\mathrm{s}_{\mathrm{ij}}$ is the fraction of major $\mathrm{j}$ (say economics majors) who are in occupation $\mathrm{i}$, and where $\mathrm{K}$ is the total number of occupational groups. While $\mathrm{H}$ is normally used to measure the concentration of firms in an industry, the index is useful in our context, although its interpretation is somewhat different. Suppose all economics majors chose the same occupation, then the value of the index would be 1 . Suppose, on the other hand, that there were 10 possible occupations and economics majors were represented equally in each of them. Then the index would be:

$$
H=\sum_{i=1}^{10}(1 / 10)_{i}^{2}=1 / 10 .
$$

The greater the number of occupations and the more equal the representation in each of the occupations, the lower will be the value of $\mathrm{H}$. A more convenient way to interpret occupational variety is to use the inverse of $\mathrm{H}$,

$$
O V=H^{-1}=\left[\sum_{1}^{K} s_{i j}^{2}\right]^{-1} .
$$

We call this the index of occupational variety. If the distribution across occupations were equal for $\mathrm{OV}$ occupations (of $\mathrm{N}$ possible occupations), $\mathrm{OV}$ would be exactly the number of occupations in which economics majors would need to be represented in order to obtain an index 
value of $\mathrm{H}^{2}$ ' One might think of OV as the number of "effective” occupations held by individuals with a particular undergraduate major. Hannah and Kay (1977, p.55) suggest a general family of indexes for measuring industrial concentration. Our index, OV, is the HannahKay index with $\alpha=2$. In an application of the concept that we are attempting to measure, Blom, Cadena and Keys (2015) use the $\mathrm{H}$ as a measure of the occupational mobility afforded to those with a particular major. They treat this as a permanent characteristic of a major.

In order to discuss the properties of this index, it is helpful to refer to a graphical representation of the concept. Figure 3 shows the concentration curve for three hypothetical college majors, directly adapted from the concentration curve of Hannah and Kay (1977, p. 49). The curve for each major is piecewise linear, with each segment of the curve representing an occupation. The occupations are ordered from most to least popular within the major, so the first segment for major $\mathrm{C}$ need not represent the same occupation as in the first segment for major $\mathrm{A}$. (In fact, the occupations represented on A need not match any of the occupations on C.) Curves that are higher and more to the left represent more concentrated majors.

For major A, the representation in each of five different occupations is almost identical. In this case, it would be natural to measure the occupational variety as simply counting the number of occupations held by those with major A. In contrast, for those with major C, almost all are concentrated in one occupation, with a small fraction spread across three other occupations. Counting the number of occupations in this case would clearly overstate the "variety" of occupations held by those with major C. OV measures variety by counting the

\footnotetext{
${ }^{2}$ In the context of measuring the diversity of species represented in an ecological
} community, OV is called “Simpson’s diversity index.” (See Magurran, 1988.) 
number of "effective" occupations - the number of equally sized occupations that would yield the observed $\mathrm{H}$ value for that major.

Clearly, major A has more occupational variety than B or C. However, the ranking between $\mathrm{B}$ and $\mathrm{C}$ is uncertain, since these curves cross. A numerical index that provides a complete ranking will involve implicit value judgements when concentration curves cross. But there are some properties that are desirable for any such index. Hannah and Kay (1977, pp. 4855) propose several reasonable and intuitive properties which we adapt slightly for this application:

V1. Dominance: If one concentration curve is everywhere above another concentration curve, the former represents a higher level of concentration (hence a lower level of occupational variety).

V2. Transfers: Moving a worker from a less popular occupation within a major to a more popular occupation represents an increase in concentration, decreasing variety. V3. New occupations: Adding a new occupation to the distribution without changing the relative sizes of existing occupations will reduce concentration as long as the new occupation is not too large. (Additional occupations increase variety, if not too large.) V4. Aggregation: Aggregating occupations leads to higher levels of concentration. (Merging occupational groups leads to lower variety.)

Hannah and Kay (1977) show that indexes of the type we propose obey V1-V4. Thus we can state the following about our index of occupational variety:

1. The value of OV depends on the definition of majors and occupational groups which are inherently ad hoc, so care must be taken when comparing the index across time or 
across different populations. If the definitions of majors or occupations differ, the indexes are not comparable.

2. If it is possible to rank variety by comparing concentration curves, OV will preserve this ranking (by V1, above).

3. Changes in the size of a major do not affect the index. Thus, it is possible to compare changes over time even if a particular major increases or decreases in popularity (since the index is defined only on the shares in each occupation).

4. Aggregation of occupational groups (say using a 2-digit versus 3-digit level of aggregation) will decrease occupational variety (by V4).

5. Broadening the definition of a major has an uncertain impact on OV, depending on the occupational distributions within the majors that are combined. The insights from applications to industrial concentration do not apply because the occupations within different majors are treated like the same "firm.” Thus, the effects of both V3 and V4 are manifested. So combining two majors with very distinctive sets of occupations, say "accounting” and "nursing” will clearly lead to higher occupational variety in the combined major of "accounting and nursing" than was observed in either of the component majors. But it is possible to construct examples of occupational distributions where OV for the combined major does not increase (if they have identical occupational distributions) or, more commonly, where the result is somewhere between the value of the two.

As OV is based on sample information, it is also a statistic. The sampling distribution of this index has been studied by Phipps (2010), who derives an estimator for the variance for the statistic, which we calculate and report for our estimates. 
In the following sections we apply these indexes to examine aspects of occupational distribution by major in the United States for the period from 1993 to about 2010. While we examine both distinctiveness and variety, we emphasize changes in variety.

\section{Data}

The primary data for this analysis comes from three waves of the National Survey of College Graduates (NSCG). The NSCG is conducted by the U.S. Census Bureau for the National Science Foundation as part of the NSF's efforts to track scientific manpower in the United States. We examine data from surveys conducted in 1993, 2003, and 2010.

The sample for the 1993 survey was drawn from individuals who responded to the long form in the 1990 Census, claimed to hold a baccalaureate (or higher) degree, and who were less than 72 years old as of April 1, 1990. The 2003 survey used a similar sampling framework, but based on the 2000 U.S. Census. In addition, it also drew some individuals from respondents to other National Science Foundation surveys. This sample represents individuals who were living in the United States on October 1, 2003, who held a baccalaureate degree or higher, and who were less than 76 years old. The 2010 survey drew part of its sample from the 2009 American Community Survey respondents who indicated that they had a bachelor's degree or higher. Part of the sample was also drawn from other National Science Foundation surveys. Technical documentation, questionnaires, and data for all three of these surveys are available through the Foundation’s SESTAT Data Tool (National Science Foundation, no date).

Table 1 summarizes the demographic characteristics of the samples that we use in our analysis, which includes only individuals who are in the labor force and who reported an occupation. Age is slightly higher for the 2003 and 2010 samples than for the 1993 sample. The 
racial composition of college graduates changed significantly over this period—Hispanic graduates have increased from about 6 percent to about 10 percent of the population holding bachelor's degrees, while Asians have increased from about 10 percent to about 16 percent. Graduate education has also increased significantly—-the fraction holding no advanced degree fell from 61 percent in 1993 to about 54 percent in 2010.

It is also important to note that labor market conditions differ across these surveys, particularly for the 2010 survey. Respondents in the 2010 NSCG report an unemployment rate of about 5 percent in 2010 compared to rates around 3.5 percent in the earlier waves. While the unemployment rate of college educated workers was much lower than for those without a college degree during the period following the 2007-2009 recession, Farber (2015) points out that college graduates experienced historically high rates of job loss in the recession leading up to 2010. This may have implications for the occupational distribution, although we are unable to examine this as a driver of the phenomena that we document in this paper.

The National Survey of College Graduates asks respondents to identify the job category that best describes the respondent's main job, or the most recent job if the respondent is not currently employed. Since the primary purpose of the survey is to analyze the scientific workforce and focuses on degree holders, the occupations tend to be more specific in some fields and less specific in others. Occupations with typically lower educational requirements are broadly grouped in categories such as "Construction trades, miners \& well drillers" or "Operators and related occupations." Thus, the spectrum of occupations that are available is narrower than we would observe in the census or the American Community Survey, for example.

To compare the occupational distribution across time periods, it is necessary for us to harmonize the occupational categories used in the different waves of the survey. Our 
harmonized set includes 116 occupation groups. Appendix B explains how we grouped occupations in each survey for those small number of cases where it was necessary to combine occupation groups in order to maintain consistency over the entire study period. To the extent that the changes in definitions represent "new" occupations in later surveys, our approach will understate the true changes in occupational variety. However, almost all of these potentially new occupations are in the computer and information science fields, so any understatement is likely limited to a few majors with significant employment in computer related fields. The increased detail in the management related fields in the later surveys does not represent new occupations.

In the 1993 wave of the NSCG, the only choice for management occupations was “Top level manager," described in the survey as "Top level and mid-level managers, executives and administrators (people who manage other managers).” All other managers were instructed to "use the code that comes closest to the field you manage.” Respondents could also choose "Other management related occupations." In the later surveys, a broad new related category was added: "Managers, other," described as "people who manage other managers." Within this group, a number of specific occupational groups were included, such as "Engineering Managers" and "Educational Administrators (e. g., registrar, dean, principal),” as well as "Other mid-level managers.” We have grouped these "Managers, other" occupations with the "Top Level” management fields in our analyses. In this case, our harmonization appears to be imperfect, but we believe this will have little impact on our overall results, as the detailed analyses in Table 6 below suggests. 
IV. Variety and Distinctiveness in the National Survey of College Graduates

Estimated values of the occupational variety index are reported in Table 2 for several selected large undergraduate majors. (These "popular” majors are among the 50 largest majors in each of the three years and constitute two thirds of all respondents in each of the three surveys.)

These indices provide numerical measures of the degree of occupational orientation of a particular major. For examples, "Nursing” has an occupational variety of less than 2. Engineering fields also have low occupational variety, in the range from about 3 to 5. Most of the undergraduate majors that we think of as vocationally or professionally oriented have relatively low values for OV, usually less than 5 . At the other end of the spectrum, some liberal arts majors have rather large values--history and English have values of OV in the low 20s. Mathematics, political science and sociology have values of OV that are quite similar to that of economics-in the mid-teens. Geology and most of the life sciences appear to be much more "vocational" than mathematics or economics, at least in 1993.

Table 3 reports corresponding values of the occupational distinctiveness index.

Figure 4 shows the relationship between OV and OD for the 1993 NSCG data for the all majors. ${ }^{3}$ The line represents a simple regression with $\mathrm{OV}$ as the independent variable, so circles above the line have higher than average distinctiveness for a given level of variety. The size of the circle reflects the sample size for that major. Obviously, the most distinctive major fields, like "Nursing" and "Pre-Med" also tend to have the lowest level of occupational variety, but the

\footnotetext{
3 The estimated indexes for all 141 majors that we analyze are reported in Appendix
} Table A1 (variety) and Appendix Table A2 (distinctiveness). 
relationship is not perfect. For example, “Accounting” and "Computer Science” both have low values of variety, but “Accounting” has a much lower distinctiveness. Accounting majors are concentrated in a few occupations, but those occupations are fairly common for individuals who hold other majors. "Computer Science” majors work in a small number of occupations where few other majors are found. "General Psychology” and “Anthropology \& Archeology” have similar levels of distinctiveness but much different levels of variety. "Physics" and "General Psychology” have very similar levels of variety, but "Physics” is much more distinctive. Some small majors, like "Botany" and "Oceanography" are far above the regression line, but due to their small sample sizes, the position on the graph is subject to a lot of uncertainty.

Conceptually, OV could be low even if OD were high. For example, if everyone who received a degree in accounting worked as an accountant, then OV would have a value of 1 (very low). If graduates from other majors never became accountants, then OD would also be 1 (very high). On the other hand, if accounting were a common career for all other majors, the OD would be much lower. If accounting students took jobs in many different occupations, then OV would be high. If those occupations were limited to only those with accounting degrees, then OD would be very high, as well. In fact, the correlation between the two indices is very high (about -.78 for the 1993 NSCG sample). In this study we focus on changes in occupational variety.

\section{The Increasing Occupational Variety by Major}

For the same 32 majors reported in Tables 2, Figure 5 illustrates graphically the changes in occupational variety from 1993 to 2010. (The size of the circle representing each major is proportional to the average number of observations in the two waves of the sample. The line in 
the graph is the 45 degree line—values would fall on the line if variety had not changed between survey years.) Although occupational variety for some majors has fallen, most majors exhibit substantial increases in occupational diversity between 1993 and 2003. The congested grouping in the lower left of the figure appears to be associated with only small changes, but for these majors the changes are typically statistically significant and are proportionally quite large. Figure 6 displays the occupational variety for all majors, some of which have very small sample sizes in our data sets. In our analysis of all majors, the variety index increases for 77 percent of the majors between 1993 and 2010.

However, the above analysis ignores information in the 2003 wave of the survey, and, in fact, changes across survey waves are not entirely consistent. Figure 7 plots the change in occupational variety between the 2003 and 2010 survey years, against the change between the 1993 and 2003 waves. The points in the shaded area represent those 109 majors for which occupational variety increased between 1993 and 2010. The negative correlation between the inter-wave changes is apparent—majors which showed unusually large increases between 1993 and 2003 tend to have decreases between 2003 and 2010, and majors with decreases between the first two waves, tend to have increases between the latter two.

On the other hand, many of the changes are small, and many of the majors are represented in the sample by few individuals, so this graph fails to take into account the sampling variability of the index. Table 4 summarizes our statistical analysis of the changes between survey waves. For each major, we construct t-tests of whether the change between waves is positive or negative, under the assumption that the samples in each wave are independent. We report outcomes of 1-tailed tests, using a 5 percent significance level. We find that 63 (45 percent) showed a statistically significant increase in variety between 1993 and 2003, while 41 
(29 percent) showed a statistically significant increase between 2003 and 2010. However, only 6 majors (4 percent) showed a statistically significant decline between the first two waves, and 20 (14 percent) showed a significant decline between the latter waves. Thus, changes over time are strongly suggestive of an increase in occupational variety over this entire period, although the changes appear to be concentrated in the 1990 and early 2000s.

For occupational variety, it is possible to also calculate a value for all college majors together. Table 5 reports this value for the three waves of the NSCG along with corresponding values from the 1990 and 2000 U.S. Census, calculated from the 5\% Public Use Microsample data, along with the 2010 American Community Survey 3-year sample. In 1993, the occupational variety for all college majors, based on the NSCG sample and the NSCG occupational definitions, is about 33. In contrast, the value of OV for economics majors in 1993 is only about 16. Thus, economics majors show roughly half the occupational diversity that we observe among all college graduates. Liberal Arts/General Studies majors have the largest value of variety for 1993--about 28. History has a value of about 23, and English has a value of about 22. For comparison, the corresponding values for all college majors in the 1990 Census is about 35, while the value of OV for all job-holders, including those without a college degree, is approximately 77. For all majors together and for all workers, occupational variety has increased significantly since 1990 in the census samples as well as in the NSCG samples. But in the NSCG samples, there is a large drop in variety between 2003 and 2010.

It is important to keep in mind that those estimates based on the NSCG and those based on the census are not directly comparable, as the index value depends on the definition of occupational groups. We have not attempted to harmonize the occupational definitions between the NSCG and the census. Thus, the difference between the census and NSCG estimates reflects, 
in part, differences in the definitions of occupational categories—we observe over 300 occupations among census college graduates in 1990 versus 116 occupations among NSCG respondents in 1993. Also, changes in the "overall” measure for college graduates in Table 4 reflect two different sources of variety—variety within a particular major and variety in majors held. So, the falling overall index from 2003 to 2010 might be due to changing composition of college major, as well as changes in the distribution conditional on college major. However, the growth in occupational variety unconditional on major provides further evidence that occupations are changing in interesting ways over the period that we examine.

To study the question further, we have also examined data from the American Community Survey which began collecting information on undergraduate college major in 2009. Appendix Figure C1 shows the changes in occupational variety between 2009 and 2014 for the ACS data. Note that the ACS defines 170 fields, versus 141 in our analysis of the NSCG, and the sample sizes are typically much larger. There are no dramatic changes apparent, although there are slightly more major in which OV fell than increased. Using a 1-tailed test at the 5 percent significance level, we observe 40 (24 percent) majors with a statistically significant decline, compared to 31(18 percent) with a statistically significant increase.

The results from the ACS, along with the "all majors" results, certainly suggest that the dramatic increase in occupational variety in the 1990s has stopped, and may have slowed, or disappeared during the early 2000s.

\section{Why Has Variety Increased?}

What has been happening in the labor market to bring about these changes in the occupational distribution of those who hold college degrees in specific fields? One approach to 
answering the question is simply mechanical. OV is the inverse of the Herfindahl Index $(\mathrm{H})$, and $\mathrm{H}$ is computed by summing squares of the shares of each occupational group. So, the source of increase in OV can be identified by looking at the contribution of each occupation to the sum, since the difference in the sum can be expressed as the sum of the differences. In order for variety to increase, the distribution across occupations must have become somehow more evenoccupations with higher shares must have fallen in popularity, and occupations with lower shares must have increased. In Table 6 we identify the "source" of the changes for three interesting cases from among the most popular majors: Biology, Sociology, and Elementary Teacher Education. These all show large increases in variety, either in absolute or relative terms.

For each major, we list six occupations that are particularly important in determining the $\mathrm{H}$ index (and thus the OV index) for that major. The first three are those that have the strongest effect in reducing $\mathrm{H}$ (increasing $\mathrm{OV}$ ), and the last three have the strongest effect in increasing $\mathrm{H}$ (and thus decreasing OV). The far right hand column of the table shows the changes in OV and $\mathrm{H}$. The change in $\mathrm{H}$ can simply be attributed to related changes in shares $(S)$ of each occupation because the change in $\mathrm{H}$ can also be expressed as the sum of changes in the squares of the shares. The top panel of Table 6 shows this analysis for biology. The change in $\mathrm{H}$ is -.055 (resulting in an increase in OV of 12.77). Between 1993 and 2010, the share of biology majors who worked as health care practitioners (what the NSCG calls “diagnosing and treating practitioners”-including physicians, dentists, optometrists) fell from about 28 percent to about 12 percent. The resulting difference in squares of shares is -.064. This is actually larger than the total change in $\mathrm{H}$, so changes in other occupations mitigate the effect of the decline in the share working as health practitioners. Although we do not report the analysis here, an almost identical change occurred for those in the zoology major, and a similar change occurred for the 
biochemistry major. Thus, for three majors in the life sciences field, the dramatic change in occupational variety is mostly attributable to the dramatic decline in the number of majors who work in this single occupational area. Biology is much less of a "pre-med" or "pre-dental" major than it was twenty years previously.

The table also shows where the biggest increase in concentration has occurred-in this case, "other management," "secondary school teachers,” and "biological scientists.” However, these changes are all small relative to the change in the share of majors who work as health practitioners. This implies that the shift from health practitioners has been absorbed across a large number of different occupations.

A very similar pattern is visible in the case of sociology and elementary teacher education as well. In the case of sociology, the major decline occurs in the occupation of social worker. In the case of elementary teacher education, the decline is in elementary school teaching. In all three of the cases we examine in Table 6, the decline in the largest occupational group is more than enough to explain the overall change.

The above discussion is purely mechanical. It is likely that an individual analysis of changes in each major would provide insights into the particular aspects of the labor market that connects that college major with various occupations. However, it is unlikely that such an analysis would provide insights into the broader economic and social forces that have led to similar changes across a broad range of distinctive majors. It is unlikely that the forces affecting teacher education majors are the same forces that affect biochemistry majors.

We consider broadly two types of influences that might affect the occupational distribution. We refer to them as "push" and "pull." "Push" forces relate to an imbalance between higher education and the labor market and relate to the ideas of over-education and 
educational mismatch. If push forces dominate, fewer students are able to find jobs in the fields in which they are trained, so they seek jobs in other fields. This might be due to colleges and universities producing too many graduates for the jobs available in the economy. In the short run, changes in technology and tastes result in large reductions in the need for certain types of skills that may be associated with the college major. A recent example would be the sudden fall in petroleum prices, which has led to a dramatic reduction in drilling and petroleum exploration in the United States. Students who are now graduating with degrees in petroleum engineering are finding it very difficult to get jobs in the field. (Ailworth, 2015). Five years ago, all of these petroleum engineering graduates would be working in petroleum engineering occupations. Now they are forced to find jobs in other occupations. Thus, the occupational variety of petroleum engineering graduates has increased in this time period. Another example is how the expansion of the internet has disrupted the newspaper publishing industry. This has led to dramatic declines in the number of jobs available for newspaper reporters. Thus, many with journalism degrees who once worked as newspaper reporters have been forced out of their preferred field. This provides an explanation for the large change in occupational variety that we observe for journalism graduates, whose OV increased from 8 to about 17 between 1993 and 2010.

There is a large literature on "overeducation” and "occupational mismatch,” although little of it touches directly on the connection between college major and education. Typical studies consider the educational requirements of a job. For example, Abel and Dietz (2015) link data from the O*Net database to identify jobs that "require” a college education. They find that a large fraction (almost 35 percent) of college graduates work in jobs that do not require a college degree. Other studies use surveys that ask respondents directly whether their job requires a college degree, such as Sicherman (1991). Robst (2007) actually addresses the question of 
whether an individual's work is related to their field of study. Most of these studies document the fact that: (1) Many college graduates apparently work in occupations that either do not require a college degree, or that use skills unrelated to the degree earned by an individual, and (2) Those who labor under such mismatch earn less money.

More generally, Beaudry, Green and Sand (2016) argue that the demand for cognitive skills has been decreasing since about 2000, and as a result, highly skilled workers have moved “down the occupational ladder” by taking jobs formerly held by less educated workers. Thus, their model would predict a broadening of the occupational distributions for many different college majors, which we do not observe.

Somewhat paradoxically, there is also a literature that suggests that there are too few college graduates with certain needed skills, epitomized in recent policies to increase the number of students studying the so-called STEM (science, technology, engineering, and math) fields. This idea is documented and reviewed critically in Capelli (2015).

On the other hand, some types of technical change may "pull” workers from one major into a field that was not previously associated with that major. Consider the dramatic changes in the financial industry--jobs that might once have been filled by economics or finance graduates might now be filled by physics or mathematics graduates. The growth of the biotechnology industry has changed the job options available to those with biology and biochemistry degrees and likely has changed the type of student who studies those fields. The dramatic changes in retail and advertising created new opportunities for majors in marketing or computer science. The effect of pull forces is to reduce the concentration of majors in the types of jobs that have traditionally been associated with the major and thus increase the occupational variety of those majors. 
We do not have a way to test directly these alternative theories, although it seems likely that both push and pull forces are at work in the labor market. The period we have analyzed here clearly is a period of rapid technological change, so it is not too surprising that the relationship between college major and occupation has changed, too.

One thing we can examine is the self-reported match between an individual's work and their field of study. In each of the waves of the NSCG, employed respondents were asked the question: “To what extent was your work on your principle job . . . related to your highest degree?” Table 7 reports the responses to this question for holders of various degrees. Overall, the reported relatedness of degree and work actually increased slightly from 1993 to 2010, from about 80 percent to about 81 percent. The same pattern is observed for all types of highest degree, with the exception that those with professional degrees are slightly less likely to be closely related to their field of study. For those whose highest degree is a bachelor's degree, about 75 percent of employees do work that is at least somewhat related to the field of their degree, and almost half do work that is closely related to their degree. Thus, increasing occupational variety has not been associated with increasing mismatch between college degree and work tasks. This provides at least some support for the idea that increasing occupational variety is the result of graduates finding new occupational places in the labor market that take advantage of their field of study.

\section{Conclusions}

In this paper we have suggested two indices to describe the occupational distribution for undergraduate major fields. Occupational distinctiveness, OD, measures the occupational segregation of individuals with a particular major. Occupational variety, $\mathrm{OV}$, measures the 
dispersion of these individuals across occupations. Obviously, these measures are not independent, although we show that they are not deterministically linked.

We apply these indices to data from the National Survey of College Graduates. The most significant finding is that occupational variety increased substantially for most majors during the past two decades, although our analysis suggests that most of the change occurred in the 1990s or early 2000s.

We discuss some reasons why the changes in technology and tastes may influence the occupational distribution of those in a particular college major. On the one hand, these forces might make it difficult for graduates with particular majors to find work in the planned occupations, which would lead to greater mismatch between college major and occupation. On the other hand, changes may create new labor market niches for those with a particular major, pulling them away from occupations traditionally associated with that major.

We examine the question of education-occupation mismatch and find that workers in 2010 are just as likely as workers in 1993 to report that their work is at least somewhat related to the degree that they hold. Thus, the dramatic changes in occupational diversity do not appear to come at the expense of greater mismatch between field of study and job. 


\section{References}

Abel, Jaison R. and Richard Deitz. (2015) “Underemployment in the Early Careers of College Graduates Following the Great Recession.” Staff Report No. 749, Federal Reserve Bank of New York.

Ailworth, Erin. (2015) “Business News: Who Will Hire a Petroleum Engineer Now?” The Wall Street Journal, Page B3. May 9, 2015, New York: Dow Jones \& Company, Inc.

Albelda, Randy P. (1986) “Occupational Segregation by Race and Gender, 1958-1981.” Industrial and Labor Relations Review. 39(3): 404-411.

Altonji, Joseph G., Peter Arcidiacono and Arnaud Maurel (2015) “The Analysis of Field Choice in College and Graduate School: Determinants and Wage Effects,” Working Paper 21655, National Bureau of Economic Research.

Altonji, Joseph G., Erica Blom, and Costas Meghir. (2012), 'Heterogeneity in Human Capital Investments: High School Curriculum, College Major, and Careers’, Annual Review of Economics. 4: 185-223

Arcidiacono, Peter (2004) "Ability Sorting and the Returns to College Major." Journal of Econometrics 121(1-2): 343-375.

Beaudry, Paul, David A. Green and Benjamin M. Sand. (2016) “The Great Reversal in the Demand for Skill and Cognitive Tasks,” Journal of Labor Economics,” 34 (1, part 2), S199-S247.

Blom, Erica, Brian C. Cadena and Benjamin J. Keys. (2015) “Investment Over the Business Cycle: Insights from College Major Choice,” IZA Discussion Paper No. 9167, Institute for the Study of Labor. 
Capelli, Peter H. (2015) “Skill Gaps, Skill Shortages, and Skill Mismatches: Evidence and Arguments for the United States,” ILR Review, 68(2), 251-290.

Farber, Henry S. (2015) “Job Loss in the Great Recession and its Aftermath: U. S. Evidence from the Displaced Workers Survey.” Working Paper \#589, Industrial Relation Section, Princeton University.

Freeman, J. A. and B. T. Hirsch (2008). "College Majors and the Knowledge Content of Jobs." Economics of Education Review 27(5): 517-535.

Hannah, Leslie. and J. A. Kay (1977). Concentration in Modern Industry: Theory, Measurement and the U. K. Experience. London: Macmillan.

Hutchens, Robert. (1991) “Segregation Curves, Lorenz Curves, and Inequality in the Distribution of People Across Occupations.” Mathematical Social Sciences 21(1): 3151.

Hutchens, Robert. (2004) “One Measure of Segregation.” International Economic Review 45(2): 555-578.

Long, Mark, Dan Goldhaber, Nick Huntington-Klein. (2014) “Do Completed College Majors Respond to Changes in Wages?” Economics of Education Review. 49: 1-14.

Magurran, Anne E. (1988) Ecological Diversity and its Measurement. Princeton University Press, Princeton, NJ.

Montmarquette, Claude, Kathy Cannings, and Sophie Mahseredjian. (2002) "How Do Young People Choose College Majors?" Economics of Education Review 21(6): 543-556.

National Science Foundation, (no date) “SESTAT Data Tool,” http://sestat.nsf.gov/datadownload/ 
Phipps, Aaron. (2010) “Statistical Properties of Monopoly Indices,” unpublished Honors Program Thesis, Brigham Young University, Provo, Utah.

Ransom, Michael R. (1990) "Gender Segregation by Field in Higher Education.” Research in Higher Education, 31, 477-494.

Ransom, Michael R. (2000) "Sampling Distributions of Segregation Indices," Sociological Methods \& Research, Vol. 28, No. 4, pp. 454-475.

Robst, John. (2007) "Education and job match: The relatedness of college major and work," Economics of Education Review. 26: 397-407

Sicherman, Nahum. (1991) “'Overeducation” in the Labor Market.” Journal of Labor Economics, 9(2): 101-122.

Yamaguchi, Shintaro. (2010). "The effect of match quality and specific experience on career decisions and wage growth." Labour Economics 17(2): 407-42. 


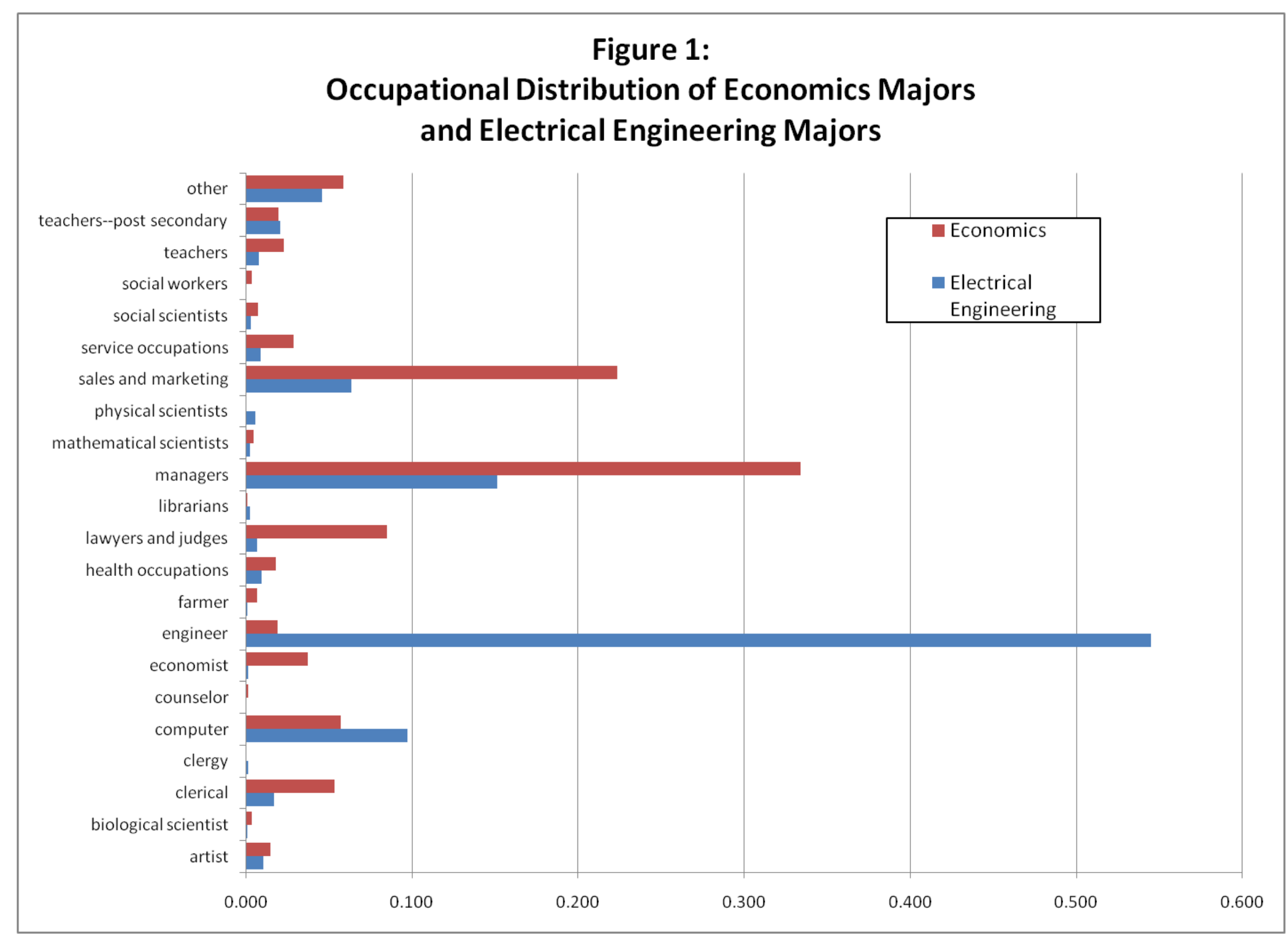




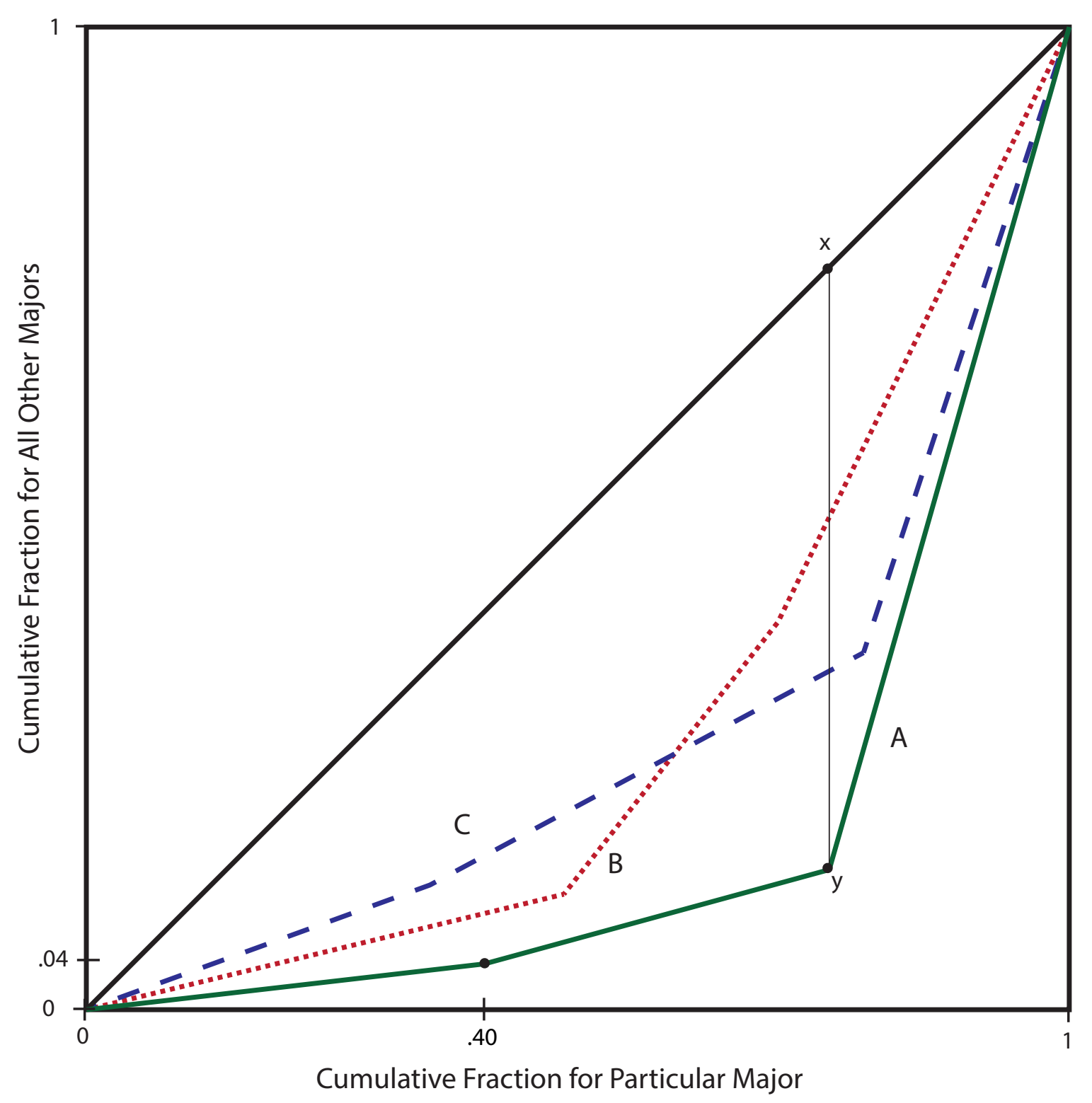

Figure 2: Segregation Curves for Three Hypothetical Majors 


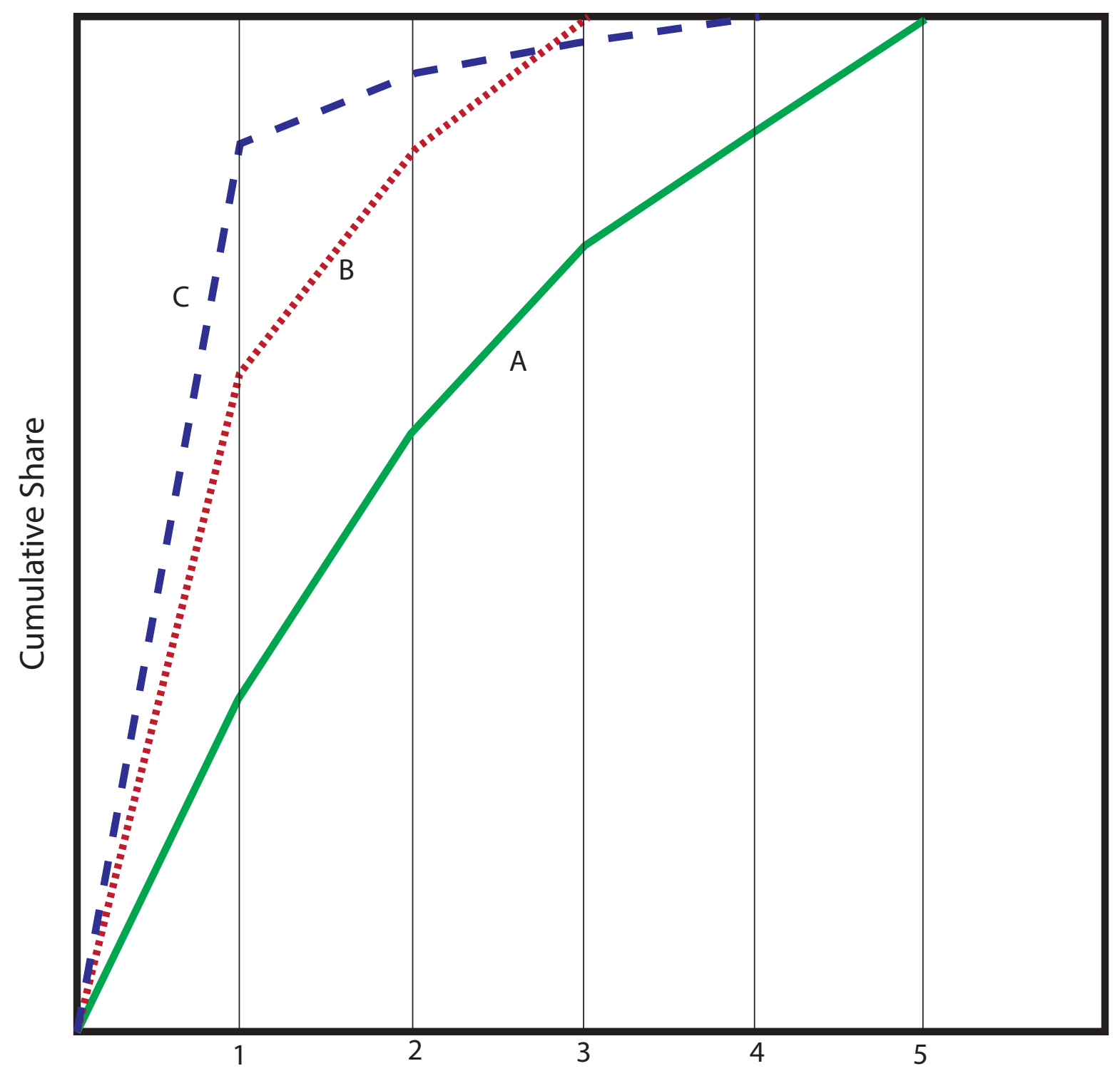

Number of Occupations (Ordered by Popularity within Major)

Figure 3: Concentration Curves for Three Hypothetical Majors 


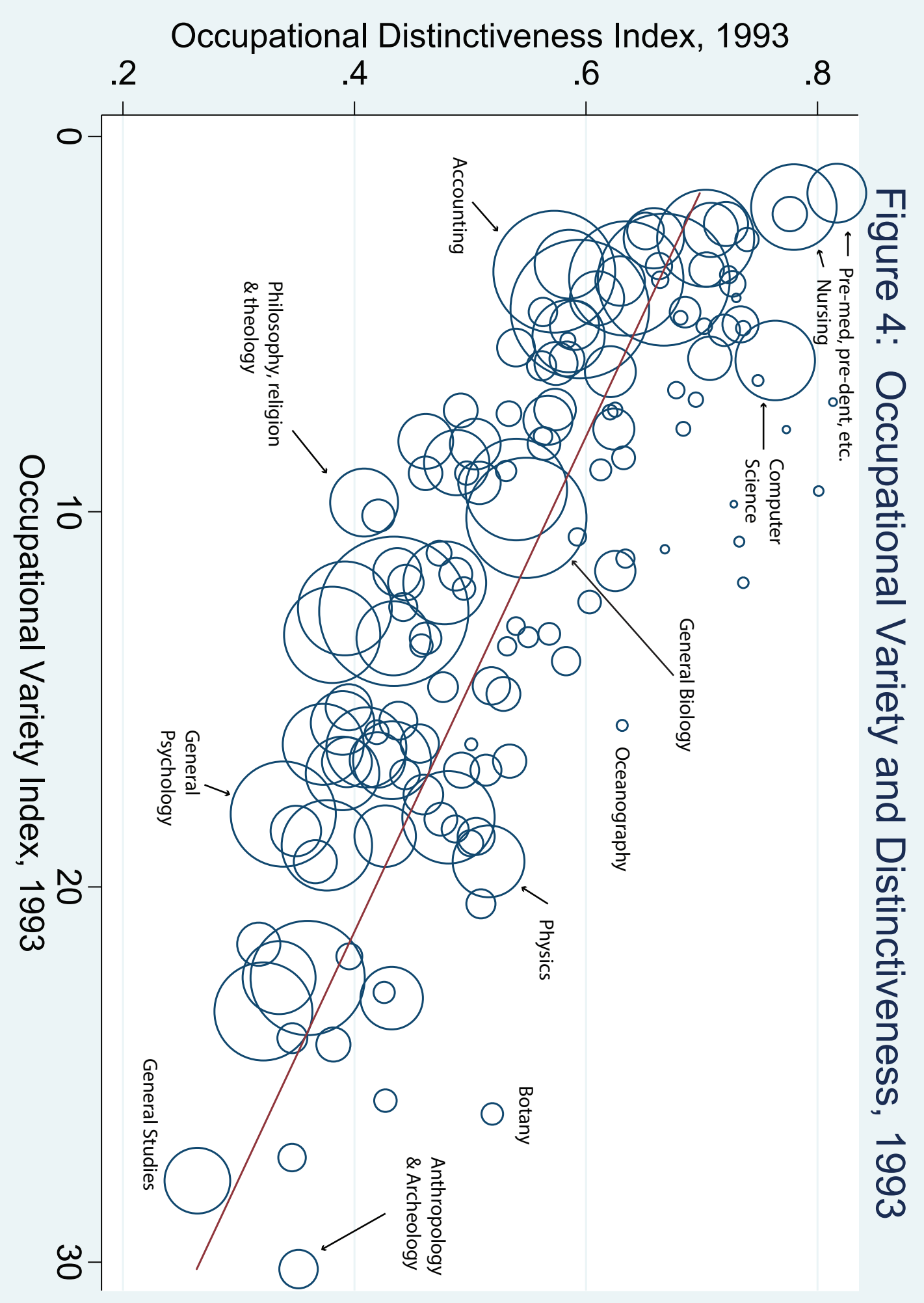




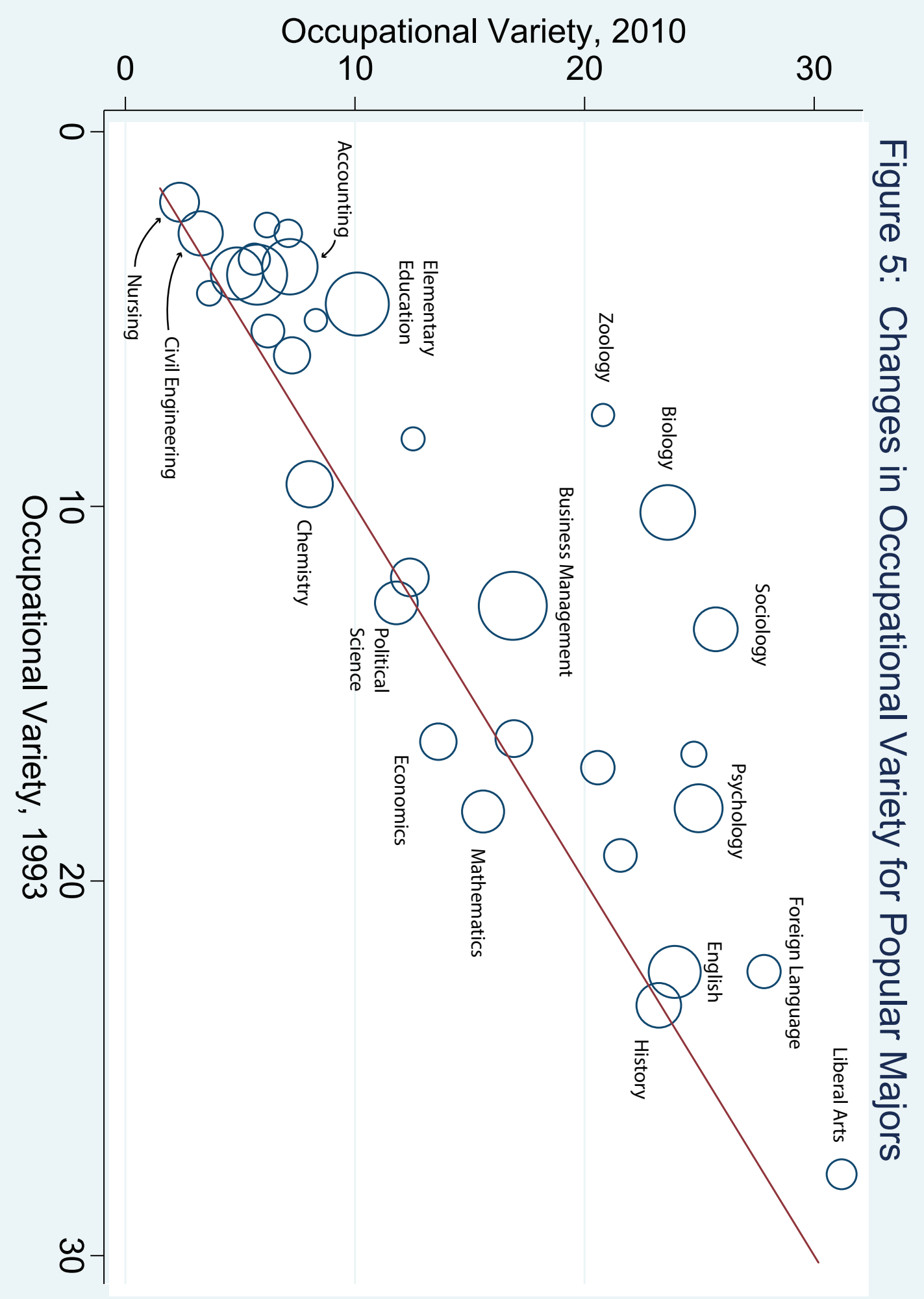




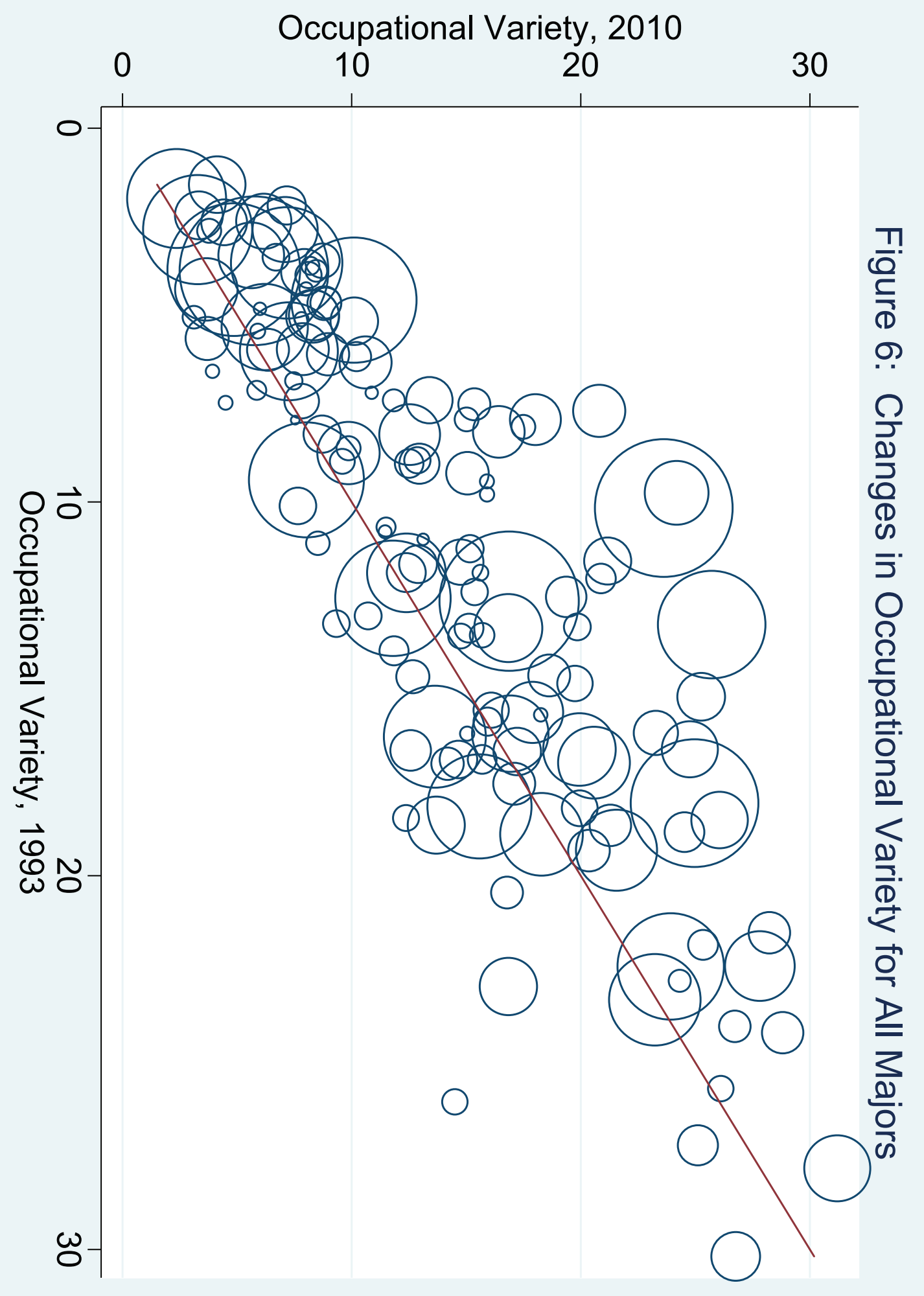




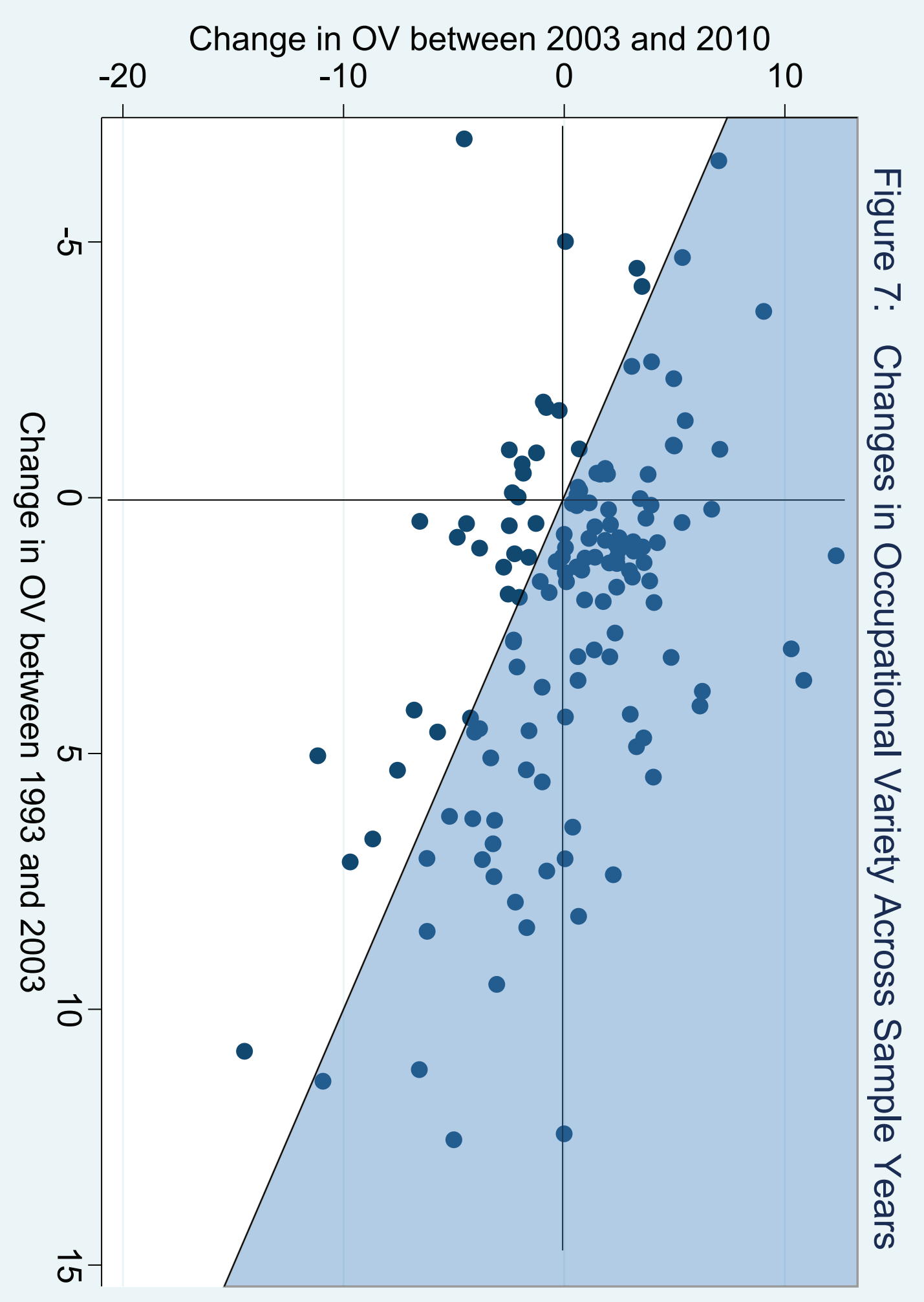


Table 1

Summary Demographic Statistics

Sample Year

\begin{tabular}{|c|c|c|c|c|c|c|}
\hline \multirow[b]{2}{*}{$\underline{\text { Variable }}$} & \multicolumn{2}{|c|}{1993} & \multicolumn{2}{|c|}{2003} & \multicolumn{2}{|c|}{2010} \\
\hline & Mean & $\begin{array}{l}\text { Standard } \\
\text { Deviation }\end{array}$ & Mean & $\begin{array}{l}\text { Standard } \\
\text { Deviation }\end{array}$ & Mean & $\begin{array}{l}\text { Standard } \\
\text { Deviation }\end{array}$ \\
\hline Age & 42.699 & 10.225 & 45.206 & 10.605 & 44.688 & 12.172 \\
\hline Female & 0.393 & 0.488 & 0.412 & 0.492 & 0.424 & 0.494 \\
\hline \multicolumn{7}{|l|}{ Highest Degree: } \\
\hline Bachelor & 0.611 & 0.487 & 0.542 & 0.498 & 0.535 & 0.499 \\
\hline Masters & 0.271 & 0.445 & 0.307 & 0.461 & 0.339 & 0.473 \\
\hline Doctorate & 0.055 & 0.228 & 0.087 & 0.282 & 0.066 & 0.249 \\
\hline Professional & 0.062 & 0.242 & 0.064 & 0.244 & 0.060 & 0.237 \\
\hline \multicolumn{7}{|l|}{ Race: } \\
\hline Native American & 0.009 & 0.094 & 0.005 & 0.072 & 0.008 & 0.091 \\
\hline Asian & 0.097 & 0.296 & 0.119 & 0.323 & 0.161 & 0.367 \\
\hline Black & 0.091 & 0.287 & 0.074 & 0.262 & 0.095 & 0.294 \\
\hline White & 0.740 & 0.439 & 0.712 & 0.453 & 0.613 & 0.487 \\
\hline \multicolumn{7}{|l|}{ Ethnicity: } \\
\hline Hispanic (all races) & 0.063 & 0.243 & 0.070 & 0.256 & 0.102 & 0.302 \\
\hline Unemployed & 0.032 & 0.175 & 0.037 & 0.188 & 0.050 & 0.218 \\
\hline Sample Size & & 837 & & ,350 & 63 & \\
\hline
\end{tabular}


Table 2

Occupational Variety for Popular Majors

\begin{tabular}{|c|c|c|c|c|c|c|}
\hline \multirow[b]{2}{*}{ Math and Sciences } & \multicolumn{2}{|c|}{1993} & \multicolumn{2}{|c|}{$\underline{2003}$} & \multicolumn{2}{|c|}{$\underline{2010}$} \\
\hline & $\underline{\mathrm{OV}}$ & $\underline{\text { St Err }}$ & $\underline{\mathrm{OV}}$ & $\underline{\text { St Err }}$ & $\underline{\mathrm{OV}}$ & $\underline{\text { St Err }}$ \\
\hline Computer science & 5.97 & 0.14 & 5.40 & 0.16 & 7.26 & 0.27 \\
\hline Mathematics, general & 18.15 & 0.50 & 17.49 & 0.60 & 15.58 & 0.65 \\
\hline Biology, general & 10.16 & 0.35 & 11.30 & 0.46 & 23.62 & 0.68 \\
\hline Zoology, general & 7.56 & 0.61 & 10.52 & 1.14 & 20.81 & 1.72 \\
\hline Chemistry, except biochemistry & 9.41 & 0.33 & 10.77 & 0.51 & 8.03 & 0.39 \\
\hline Geology & 4.31 & 0.28 & 6.20 & 0.58 & 3.66 & 0.24 \\
\hline Physics & 19.32 & 0.91 & 19.55 & 0.94 & 21.56 & 1.28 \\
\hline \multicolumn{7}{|l|}{$\underline{\text { Social Sciences }}$} \\
\hline Economics & 16.28 & 0.69 & 20.43 & 0.80 & 13.63 & 0.45 \\
\hline Political science and government & 12.58 & 0.47 & 13.08 & 0.66 & 11.80 & 0.46 \\
\hline General psychology & 18.06 & 0.56 & 18.28 & 0.72 & 24.97 & 0.63 \\
\hline Sociology & 13.28 & 0.53 & 25.72 & 1.28 & 25.71 & 0.91 \\
\hline Social Work & 3.40 & 0.15 & 4.82 & 0.33 & 5.62 & 0.63 \\
\hline \multicolumn{7}{|l|}{ Engineering } \\
\hline Aerospace \& related engineering & 5.03 & 0.34 & 5.81 & 0.55 & 8.30 & 0.86 \\
\hline Chemical engineering & 5.32 & 0.26 & 6.57 & 0.41 & 6.21 & 0.32 \\
\hline Civil engineering & 2.71 & 0.07 & 2.57 & 0.08 & 3.28 & 0.11 \\
\hline Electrical, electronics \& related engineering & 3.82 & 0.09 & 5.17 & 0.15 & 5.74 & 0.17 \\
\hline Industrial and manufacturing engineering & 8.20 & 0.56 & 11.17 & 0.94 & 12.53 & 0.80 \\
\hline Mechanical engineering & 3.79 & 0.10 & 4.94 & 0.17 & 4.86 & 0.16 \\
\hline \multicolumn{7}{|l|}{ Health Related } \\
\hline Health/medical technologies & 2.49 & 0.12 & 3.78 & 0.32 & 6.17 & 0.69 \\
\hline Nursing & 1.88 & 0.05 & 2.00 & 0.06 & 2.36 & 0.08 \\
\hline \multicolumn{7}{|l|}{ Business } \\
\hline Accounting & 3.60 & 0.08 & 4.79 & 0.17 & 7.16 & 0.57 \\
\hline Business administration and management & 12.65 & 0.30 & 20.06 & 0.44 & 16.87 & 0.94 \\
\hline Business, general & 16.97 & 0.68 & 22.29 & 0.89 & 20.58 & 1.48 \\
\hline $\begin{array}{l}\text { Business marketing/marketing management } \\
\qquad \text { Education }\end{array}$ & 11.90 & 0.37 & 14.68 & 0.62 & 12.39 & 1.02 \\
\hline Elementary teacher education & 4.60 & 0.11 & 6.23 & 0.25 & 10.10 & 0.99 \\
\hline Secondary teacher education & 16.20 & 0.77 & 16.35 & 1.12 & 16.92 & 1.76 \\
\hline \multicolumn{7}{|l|}{ Humanities \& Other Fields } \\
\hline English Language, literature and letters & 22.43 & 0.56 & 21.97 & 0.71 & 23.93 & 1.85 \\
\hline Foreign languages and literature & 22.42 & 0.99 & 18.77 & 1.15 & 27.82 & 2.37 \\
\hline Liberal Arts/General Studies & 27.83 & 1.21 & 34.90 & 1.69 & 31.20 & 2.56 \\
\hline History & 23.32 & 0.78 & 25.27 & 1.03 & 23.23 & 1.98 \\
\hline Architecture/Environmental Design & 2.71 & 0.12 & 4.14 & 0.30 & 7.10 & 0.55 \\
\hline Communications, general & 16.62 & 0.90 & 21.48 & 1.16 & 24.76 & 2.17 \\
\hline
\end{tabular}


Table 3

Occupational Distinctiveness for Popular Majors

\begin{tabular}{|c|c|c|c|c|c|c|}
\hline \multirow[b]{2}{*}{$\underline{\text { Math and Sciences }}$} & \multicolumn{2}{|c|}{1993} & \multicolumn{2}{|c|}{$\underline{2003}$} & \multicolumn{2}{|c|}{$\underline{2010}$} \\
\hline & $\underline{\mathrm{OD}}$ & $\underline{\text { St Err }}$ & $\underline{\mathrm{OD}}$ & $\underline{\text { St Err }}$ & $\underline{\mathrm{OD}}$ & $\underline{\text { St Err }}$ \\
\hline Computer science & 0.763 & 0.008 & 0.693 & 0.008 & 0.577 & 0.010 \\
\hline Mathematics, general & 0.481 & 0.010 & 0.485 & 0.011 & 0.455 & 0.011 \\
\hline Biology, general & 0.549 & 0.007 & 0.550 & 0.008 & 0.423 & 0.009 \\
\hline Zoology, general & 0.567 & 0.017 & 0.520 & 0.022 & 0.427 & 0.025 \\
\hline Chemistry, except biochemistry & 0.540 & 0.008 & 0.531 & 0.010 & 0.511 & 0.010 \\
\hline Geology & 0.610 & 0.016 & 0.598 & 0.020 & 0.620 & 0.018 \\
\hline Physics & 0.516 & 0.011 & 0.509 & 0.012 & 0.416 & 0.014 \\
\hline \multicolumn{7}{|l|}{$\underline{\text { Social Sciences }}$} \\
\hline Economics & 0.410 & 0.008 & 0.408 & 0.010 & 0.466 & 0.008 \\
\hline Political science and government & 0.392 & 0.008 & 0.433 & 0.010 & 0.457 & 0.007 \\
\hline General psychology & 0.338 & 0.008 & 0.386 & 0.010 & 0.413 & 0.008 \\
\hline Sociology & 0.381 & 0.008 & 0.368 & 0.012 & 0.412 & 0.009 \\
\hline \multicolumn{7}{|l|}{ Engineering } \\
\hline Aerospace \& related engineering & 0.590 & 0.017 & 0.563 & 0.019 & 0.525 & 0.023 \\
\hline Chemical engineering & 0.585 & 0.011 & 0.563 & 0.014 & 0.537 & 0.011 \\
\hline Civil engineering & 0.703 & 0.007 & 0.716 & 0.008 & 0.682 & 0.009 \\
\hline Electrical \& related engineering & 0.667 & 0.006 & 0.624 & 0.007 & 0.589 & 0.006 \\
\hline Industrial and manufacturing engineering & 0.504 & 0.015 & 0.469 & 0.016 & 0.466 & 0.015 \\
\hline Mechanical engineering & 0.635 & 0.006 & 0.605 & 0.007 & 0.575 & 0.008 \\
\hline \multicolumn{7}{|l|}{$\underline{\text { Health Related }}$} \\
\hline Health/medical technologies & 0.708 & 0.014 & 0.656 & 0.020 & 0.579 & 0.024 \\
\hline Nursing & 0.780 & 0.008 & 0.764 & 0.010 & 0.709 & 0.010 \\
\hline \multicolumn{7}{|l|}{ Business } \\
\hline Accounting & 0.573 & 0.006 & 0.536 & 0.008 & 0.478 & 0.016 \\
\hline Business administration and management & 0.434 & 0.005 & 0.429 & 0.006 & 0.368 & 0.012 \\
\hline Business, general & 0.390 & 0.008 & 0.391 & 0.011 & 0.371 & 0.018 \\
\hline \multicolumn{7}{|l|}{ Education } \\
\hline Elementary teacher education & 0.595 & 0.006 & 0.589 & 0.008 & 0.579 & 0.017 \\
\hline Secondary teacher education & 0.373 & 0.011 & 0.427 & 0.013 & 0.496 & 0.024 \\
\hline Social Work & 0.585 & 0.012 & 0.592 & 0.016 & 0.559 & 0.023 \\
\hline $\begin{array}{c}\text { Business marketing/marketing management } \\
\text { Humanities \& Other Fields }\end{array}$ & 0.478 & 0.008 & 0.487 & 0.011 & 0.432 & 0.018 \\
\hline English Language, literature and letters & 0.360 & 0.008 & 0.405 & 0.010 & 0.426 & 0.019 \\
\hline Foreign languages and literature & 0.335 & 0.012 & 0.407 & 0.015 & 0.398 & 0.024 \\
\hline Liberal Arts/General Studies & 0.264 & 0.012 & 0.287 & 0.017 & 0.268 & 0.020 \\
\hline History & 0.321 & 0.008 & 0.364 & 0.011 & 0.410 & 0.020 \\
\hline Communications, general & 0.420 & 0.012 & 0.375 & 0.015 & 0.390 & 0.024 \\
\hline Architecture/Environmental Design & 0.659 & 0.013 & 0.599 & 0.015 & 0.524 & 0.015 \\
\hline
\end{tabular}


Table 4

Summary of Statistical Significance of Changes between Survey Waves

\begin{tabular}{lcccc} 
& \multicolumn{4}{c}{ Change 2003-2010 } \\
\hline Change, 1993-2003 & $\begin{array}{c}\text { Significant } \\
\text { Decline }\end{array}$ & $\begin{array}{c}\text { No Significant } \\
\text { Change }\end{array}$ & $\begin{array}{c}\text { Significant } \\
\text { Increase }\end{array}$ & Total \\
\hline Significant Decline & 0 & 2 & 4 & 6 \\
No Significant Change & 5 & 47 & 20 & 72 \\
Significant Increase & 15 & 31 & 17 & 63 \\
\cline { 2 - 5 } Total & 20 & 80 & 41 & 141
\end{tabular}


Table 5

Occupational Variety Index Values

All Majors and All Workers

\begin{tabular}{rrrrr}
\hline \multicolumn{2}{c}{ NSCG RESULTS } & \multicolumn{3}{c}{ CENSUS RESULTS } \\
\hline \multicolumn{1}{c}{$\begin{array}{c}\text { All } \\
\text { Year }\end{array}$} & $\begin{array}{c}\text { College Grads } \\
\text { Cll }\end{array}$ & \multicolumn{2}{c}{ All } \\
1993 & 33.29 & Year & Workers & College Grads \\
2003 & 43.06 & 1990 & 76.59 & 36.63 \\
2010 & 35.66 & 2000 & 89.31 & 46.51 \\
& & 2010 & 83.70 & 45.42
\end{tabular}


Table 6

Effects of Influential Occupations for Selected Majors

Biology

\begin{tabular}{|c|c|c|c|c|c|}
\hline & \multicolumn{2}{|c|}{1993} & \multicolumn{2}{|l|}{2010} & Difference \\
\hline $\mathrm{O}_{v}$ & \multicolumn{2}{|c|}{10.163} & \multicolumn{2}{|c|}{23.622} & 13.46 \\
\hline $\mathrm{H}$ & \multicolumn{2}{|c|}{0.098} & \multicolumn{2}{|c|}{0.044} & -0.055 \\
\hline Occupation & Share $(S)$ & $\underline{S^{2}}$ & Share $(S)$ & $\underline{S^{2}}$ & $\underline{S_{10}^{2}-S_{93}^{2}}$ \\
\hline Health practitioners & 0.278 & 0.077 & 0.115 & 0.013 & -0.064 \\
\hline Health technologists \& etc. & 0.068 & 0.005 & 0.026 & 0.001 & -0.004 \\
\hline Operators \& related & 0.018 & 0.000 & 0.004 & 0.000 & -0.000 \\
\hline Biological scientists & 0.045 & 0.002 & 0.061 & 0.004 & 0.002 \\
\hline Mid \& Upper Management & 0.070 & 0.005 & 0.084 & 0.007 & 0.002 \\
\hline Secondary school teachers & 0.050 & 0.002 & 0.069 & 0.005 & 0.002 \\
\hline \multicolumn{6}{|c|}{ Sociology } \\
\hline & \multicolumn{2}{|c|}{$\underline{1993}$} & \multicolumn{2}{|l|}{$\underline{2010}$} & Difference \\
\hline $\mathrm{O}_{v}$ & \multicolumn{2}{|c|}{13.282} & \multicolumn{2}{|c|}{25.714} & 12.432 \\
\hline $\mathrm{H}$ & \multicolumn{2}{|c|}{0.075} & \multicolumn{2}{|l|}{0.039} & -0.036 \\
\hline Occupation & $\underline{\text { Share }(S)}$ & $\underline{S^{2}}$ & $\underline{\text { Share }(S)}$ & $\underline{S^{2}}$ & $\underline{S_{10}^{2}-S_{93}^{2}}$ \\
\hline Social worker & 0.210 & 0.044 & 0.073 & 0.005 & -0.039 \\
\hline Mid \& Upper Management & 0.132 & 0.017 & 0.106 & 0.011 & -0.006 \\
\hline "Other" occupation & 0.038 & 0.001 & 0.016 & 0.000 & -0.001 \\
\hline Judges \& Lawyers & 0.026 & 0.001 & 0.042 & 0.002 & 0.001 \\
\hline Other Management & 0.045 & 0.002 & 0.061 & 0004 & 0.002 \\
\hline "Other" Service Occupation & 0.021 & 0.000 & 0.051 & 0.003 & 0.002 \\
\hline \multicolumn{6}{|c|}{ Elementary Teacher Education } \\
\hline & \multicolumn{2}{|c|}{$\underline{1993}$} & \multicolumn{2}{|l|}{$\underline{2010}$} & Difference \\
\hline $\mathrm{O}_{v}$ & \multicolumn{2}{|c|}{$\overline{4.600}$} & \multicolumn{2}{|c|}{$\overline{10.101}$} & 5.501 \\
\hline $\mathrm{H}$ & \multicolumn{2}{|c|}{0.217} & \multicolumn{2}{|c|}{0.099} & -0.117 \\
\hline Occupation & Share $(S)$ & $\underline{S^{2}}$ & Share(S) & $\underline{S^{2}}$ & $\underline{S_{10}^{2}-S_{93}^{2}}$ \\
\hline Elementary school teacher & 0.446 & 0.199 & 0.279 & 0.078 & -0.122 \\
\hline Pre-Kindergarten teacher & 0.072 & 0.005 & 0.046 & 0.002 & -0.003 \\
\hline Mid \& Upper Management & 0.073 & 0.005 & 0.011 & 0.000 & -0.003 \\
\hline Counselors & 0.009 & 0.000 & 0.031 & 0.001 & 0.001 \\
\hline \multicolumn{6}{|l|}{ Post-Secondary Teacher } \\
\hline (Education Field) & 0.007 & 0.000 & 0.046 & 0.002 & 0.002 \\
\hline Other Teachers (Pre college) & 0.010 & 0.000 & 0.053 & 0.003 & 0.003 \\
\hline
\end{tabular}


Table 7

Proportion of Respondents whose Current Job is

Related to Field of Highest Degree

(Currently Employed Only)

1993

$N=123,873$

0.558

0.241

0.799

$\mathrm{N}=75,719$

0.462

$\underline{0.280}$

0.742

Closely or Somewhat Related

Highest Degree: Masters

Closely Related

Somewhat Related

Closely or Somewhat Related

Highest Degree: Doctorate

Closely Related

Somewhat Related

Closely or Somewhat Related

Highest Degree: Professional

Closely Related

Somewhat Related

Closely or Somewhat Related
$\mathrm{N}=33,605$

0.648

$\underline{0.220}$

0.868

$N=6,788$

0.788

$\underline{0.139}$

0.927

$N=7,725$

0.901

$\underline{0.048}$

0.948
2010

$N=63,553$

0.581

$\underline{0.230}$

0.811

$\mathrm{N}=33,986$

0.476

$\underline{0.270}$

0.746

$\mathrm{N}=21,552$

0.653

$\underline{0.216}$

0.869

$\mathrm{N}=4,203$

0.802

$\underline{0.134}$

0.936

$\mathrm{N}=3,812$

0.863

$\underline{0.062}$

0.925 
Appendix Table A1

Occupational Variety by College Major

\begin{tabular}{|c|c|c|c|c|c|c|}
\hline Mathematics and Sciences & $\underline{\mathrm{OV}}$ & $\underline{\text { St Err }}$ & $\underline{\mathrm{OV}}$ & $\underline{\text { St Err }}$ & $\underline{\mathrm{OV}}$ & $\underline{\text { St Err }}$ \\
\hline Computer and information sciences & 5.91 & 0.28 & 6.48 & 0.37 & 7.87 & 0.65 \\
\hline Computer science & 5.97 & 0.14 & 5.40 & 0.16 & 7.26 & 0.27 \\
\hline Computer systems analysis & 3.93 & 0.41 & 4.97 & 0.70 & 8.12 & 1.28 \\
\hline Information services and systems & 5.17 & 0.30 & 7.81 & 0.46 & 10.12 & 0.67 \\
\hline Other computer and information sciences & 7.28 & 1.04 & 12.84 & 1.77 & 11.84 & 2.07 \\
\hline Applied mathematics & 18.65 & 1.42 & 16.33 & 1.22 & 21.29 & 1.86 \\
\hline Mathematics, general & 18.15 & 0.50 & 17.49 & 0.60 & 15.58 & 0.65 \\
\hline Operations research & 10.67 & 1.63 & 17.72 & 2.78 & 11.50 & 2.32 \\
\hline Statistics & 13.26 & 1.93 & 13.76 & 1.45 & 9.33 & 1.38 \\
\hline Other mathematics & 16.89 & 1.51 & 12.40 & 2.77 & 15.70 & 2.79 \\
\hline Animal sciences & 16.18 & 1.43 & 23.24 & 2.50 & 23.28 & 1.85 \\
\hline Food sciences and technology & 8.91 & 1.52 & 13.43 & 3.01 & 9.59 & 1.50 \\
\hline Plant sciences & 16.65 & 1.76 & 17.42 & 2.59 & 12.58 & 1.38 \\
\hline Other agricultural sciences & 20.45 & 2.48 & 31.27 & 4.02 & 16.78 & 2.68 \\
\hline Biochemistry and biophysics & 7.80 & 0.70 & 11.87 & 0.95 & 18.02 & 1.23 \\
\hline Biology, general & 10.16 & 0.35 & 11.30 & 0.46 & 23.62 & 0.68 \\
\hline Botany & 26.05 & 3.05 & 19.04 & 3.09 & 14.51 & 2.54 \\
\hline Cell and molecular biology & 11.25 & 1.83 & 10.22 & 1.52 & 15.17 & 1.31 \\
\hline Ecology & 13.05 & 2.89 & 12.57 & 2.43 & 10.72 & 1.66 \\
\hline Genetics, animal and plant & 11.89 & 2.28 & 15.00 & 2.37 & 15.62 & 2.63 \\
\hline Microbiological sciences and immunology & 11.58 & 0.83 & 18.95 & 1.27 & 21.18 & 1.37 \\
\hline Nutritional sciences & 4.68 & 0.52 & 8.25 & 1.74 & 8.88 & 1.66 \\
\hline Pharmacology, human and animal & 10.80 & 2.63 & 6.10 & 1.84 & 11.46 & 1.82 \\
\hline Physiology and pathology, human and animal & 7.99 & 1.59 & 13.45 & 2.49 & 17.49 & 2.23 \\
\hline Zoology, general & 7.56 & 0.61 & 10.52 & 1.14 & 20.81 & 1.72 \\
\hline Other biological sciences & 14.64 & 1.50 & 13.63 & 1.69 & 18.62 & 1.70 \\
\hline Environmental science or studies & 18.83 & 2.43 & 26.74 & 2.89 & 24.53 & 1.95 \\
\hline Forestry sciences & 8.19 & 0.87 & 8.13 & 1.15 & 8.71 & 1.01 \\
\hline Chemistry, except biochemistry & 9.41 & 0.33 & 10.77 & 0.51 & 8.03 & 0.39 \\
\hline Atmospheric sciences and meteorology & 5.06 & 1.12 & 5.61 & 1.23 & 3.12 & 0.44 \\
\hline Earth sciences & 13.59 & 3.42 & 16.90 & 2.58 & 14.76 & 2.42 \\
\hline Geology & 4.31 & 0.28 & 6.20 & 0.58 & 3.66 & 0.24 \\
\hline Other Geological sciences, & 7.01 & 1.80 & 8.11 & 2.24 & 5.86 & 1.34 \\
\hline Oceanography & 15.70 & 3.47 & 16.86 & 4.74 & 18.25 & 3.12 \\
\hline Astronomy and astrophysics & 9.45 & 2.34 & 18.96 & 3.05 & 15.91 & 3.27 \\
\hline Physics & 19.32 & 0.91 & 19.55 & 0.94 & 21.56 & 1.28 \\
\hline Other physical sciences & 24.03 & 3.03 & 24.86 & 3.85 & 26.72 & 3.67 \\
\hline
\end{tabular}


$\underline{\text { Social Sciences }}$

\begin{tabular}{|c|c|c|c|c|c|c|}
\hline Agricultural economics & 17.00 & 1.97 & 15.13 & 1.83 & 14.19 & 1.69 \\
\hline Economics & 16.28 & 0.69 & 20.43 & 0.80 & 13.63 & 0.45 \\
\hline Public policy studies & 9.80 & 1.81 & 8.85 & 2.03 & 15.91 & 2.87 \\
\hline International relations & 12.54 & 1.58 & 18.98 & 2.27 & 19.36 & 1.37 \\
\hline Political science and government & 12.58 & 0.47 & 13.08 & 0.66 & 11.80 & 0.46 \\
\hline Educational psychology & 15.88 & 1.98 & 20.18 & 2.56 & 15.94 & 1.83 \\
\hline Clinical psychology & 8.98 & 0.89 & 7.47 & 0.81 & 12.96 & 1.30 \\
\hline Counseling psychology & 11.66 & 1.00 & 11.76 & 1.34 & 12.90 & 1.34 \\
\hline Experimental psychology & 21.85 & 2.35 & 22.88 & 2.68 & 25.34 & 3.27 \\
\hline General psychology & 18.06 & 0.56 & 18.28 & 0.72 & 24.97 & 0.63 \\
\hline Industrial/Organizational psychology & 13.57 & 2.12 & 19.84 & 3.07 & 15.70 & 2.46 \\
\hline Social psychology & 12.05 & 1.73 & 20.23 & 2.77 & 20.88 & 2.20 \\
\hline Other psychology & 15.21 & 1.02 & 19.00 & 1.95 & 25.26 & 2.18 \\
\hline Anthropology and archaeology & 30.18 & 2.33 & 29.25 & 2.66 & 26.76 & 2.10 \\
\hline Criminology & 8.97 & 1.17 & 15.74 & 2.61 & 12.51 & 1.54 \\
\hline Sociology & 13.28 & 0.53 & 25.72 & 1.28 & 25.71 & 0.91 \\
\hline Area and Ethnic Studies & 27.21 & 2.58 & 27.20 & 3.14 & 25.11 & 1.82 \\
\hline Linguistics & 25.70 & 3.00 & 19.11 & 3.02 & 26.11 & 2.96 \\
\hline Philosophy of science & 22.81 & 2.73 & 24.27 & 3.21 & 24.32 & 4.42 \\
\hline Geography & 24.20 & 2.49 & 35.38 & 2.78 & 28.81 & 2.88 \\
\hline History of science & 16.20 & 2.67 & 20.78 & 3.45 & 15.04 & 3.43 \\
\hline Social Work & 3.40 & 0.15 & 4.82 & 0.33 & 5.62 & 0.63 \\
\hline Other social sciences & 18.51 & 1.24 & 31.06 & 2.17 & 26.06 & 1.74 \\
\hline \multicolumn{7}{|l|}{ Engineering } \\
\hline Aerospace \& related engineering & 5.03 & 0.34 & 5.81 & 0.55 & 8.30 & 0.86 \\
\hline Chemical engineering & 5.32 & 0.26 & 6.57 & 0.41 & 6.21 & 0.32 \\
\hline Architectural engineering & 3.55 & 0.28 & 6.66 & 0.85 & 8.72 & 1.12 \\
\hline Civil engineering & 2.71 & 0.07 & 2.57 & 0.08 & 3.28 & 0.11 \\
\hline Computer and systems engineering & 5.01 & 0.42 & 4.55 & 0.30 & 8.35 & 0.50 \\
\hline Electrical \& related engineering & 3.82 & 0.09 & 5.17 & 0.15 & 5.74 & 0.17 \\
\hline Industrial and manufacturing engineering & 8.20 & 0.56 & 11.17 & 0.94 & 12.53 & 0.80 \\
\hline Mechanical engineering & 3.79 & 0.10 & 4.94 & 0.17 & 4.86 & 0.16 \\
\hline Agricultural engineering & 12.41 & 1.58 & 16.96 & 2.50 & 15.37 & 2.13 \\
\hline Bioengineering and biomedical engineering & 7.79 & 1.47 & 12.03 & 2.03 & 15.02 & 1.99 \\
\hline Engineering sciences, mechanics and physics & 14.86 & 1.29 & 16.13 & 1.87 & 19.75 & 2.53 \\
\hline Environmental engineering & 3.82 & 0.71 & 5.37 & 0.88 & 8.46 & 1.24 \\
\hline Engineering, general & 14.68 & 1.60 & 21.35 & 2.38 & 12.67 & 1.92 \\
\hline Geophysical and geological engineering & 7.08 & 1.84 & 9.11 & 1.72 & 10.88 & 2.04 \\
\hline Materials engineering (inc. ceramics \& textiles) & 8.88 & 1.34 & 9.74 & 1.69 & 12.87 & 2.06 \\
\hline Metallurgical engineering & 3.45 & 0.40 & 4.36 & 0.70 & 6.70 & 1.27 \\
\hline Mining and minerals engineering & 6.76 & 1.21 & 7.48 & 1.52 & 7.48 & 2.0 \\
\hline
\end{tabular}




\begin{tabular}{|c|c|c|c|c|c|c|}
\hline Naval architecture and marine engineering & 8.56 & 1.05 & 5.91 & 1.23 & 9.87 & 1.91 \\
\hline Nuclear engineering & 3.68 & 0.65 & 4.65 & 1.01 & 8.20 & 2.38 \\
\hline Petroleum engineering & 2.75 & 0.32 & 3.72 & 0.66 & 3.78 & 0.65 \\
\hline Other engineering & 16.89 & 1.58 & 22.22 & 2.49 & 14.66 & 2.07 \\
\hline \multicolumn{7}{|l|}{ Health Related Majors } \\
\hline Audiology and speech pathology & 5.93 & 0.51 & 5.72 & 0.70 & 6.35 & 0.62 \\
\hline Health services administration & 7.39 & 0.82 & 10.51 & 0.88 & 15.36 & 1.41 \\
\hline Health/medical assistants & 6.50 & 1.23 & 4.74 & 1.51 & 3.93 & 1.07 \\
\hline Health/medical technologies & 2.49 & 0.12 & 3.78 & 0.32 & 6.17 & 0.69 \\
\hline $\begin{array}{l}\text { Medical preparatory programs [e.g. pre- } \\
\text { dentistry,-me... }\end{array}$ & 1.51 & 0.04 & 2.04 & 0.12 & 4.13 & 0.47 \\
\hline Medicine & 2.07 & 0.14 & 2.95 & 0.24 & 7.17 & 0.87 \\
\hline Nursing [4 years or longer program] & 1.88 & 0.05 & 2.00 & 0.06 & 2.36 & 0.08 \\
\hline Pharmacy & 2.33 & 0.13 & 1.85 & 0.09 & 3.33 & 0.30 \\
\hline Physical therapy and rehabilitation & 2.52 & 0.18 & 3.31 & 0.30 & 4.44 & 0.38 \\
\hline Public health & 13.34 & 1.99 & 20.64 & 3.32 & 19.85 & 2.69 \\
\hline Other health/medical sciences & 7.28 & 0.58 & 9.33 & 0.83 & 13.40 & 1.39 \\
\hline \multicolumn{7}{|l|}{ Technology } \\
\hline Computer programming & 4.68 & 0.43 & 6.43 & 0.51 & 8.81 & 1.17 \\
\hline Data processing & 5.11 & 0.84 & 8.81 & 1.20 & 7.81 & 2.17 \\
\hline Electrical and electronic technologies & 6.27 & 0.44 & 10.55 & 1.13 & 10.61 & 0.96 \\
\hline Industrial production technologies & 17.54 & 1.36 & 18.71 & 1.83 & 17.10 & 2.05 \\
\hline Mechanical engineering-related technologies & 6.05 & 0.51 & 8.05 & 1.33 & 8.97 & 1.41 \\
\hline Other engineering-related technologies & 18.20 & 1.95 & 23.28 & 2.12 & 19.95 & 2.92 \\
\hline Architecture/Environmental Design & 2.71 & 0.12 & 4.14 & 0.30 & 7.10 & 0.55 \\
\hline \multicolumn{7}{|l|}{$\underline{\text { Business }}$} \\
\hline Actuarial science & 4.30 & 1.38 & 5.23 & 1.72 & 8.01 & 1.84 \\
\hline Other agricultural business and production & 18.46 & 1.93 & 18.92 & 2.51 & 12.37 & 2.29 \\
\hline Accounting & 3.60 & 0.08 & 4.79 & 0.17 & 7.16 & 0.57 \\
\hline Business administration and management & 12.65 & 0.30 & 20.06 & 0.44 & 16.87 & 0.94 \\
\hline Business, general & 16.97 & 0.68 & 22.29 & 0.89 & 20.58 & 1.48 \\
\hline Business and managerial economics & 11.61 & 0.83 & 17.92 & 1.47 & 14.76 & 1.75 \\
\hline Business marketing/marketing management & 11.90 & 0.37 & 14.68 & 0.62 & 12.39 & 1.02 \\
\hline Marketing research & 13.38 & 1.14 & 15.02 & 1.88 & 15.12 & 3.25 \\
\hline Financial management & 8.69 & 0.38 & 10.54 & 0.63 & 9.86 & 1.20 \\
\hline \multicolumn{6}{|l|}{ Education } & 1.70 \\
\hline Education administration & 5.43 & 1.30 & 16.84 & 2.74 & 5.90 & 2.19 \\
\hline Counselor education and guidance services & 7.35 & 1.61 & 8.33 & 2.50 & 4.50 & 1.15 \\
\hline Elementary teacher education & 4.60 & 0.11 & 6.23 & 0.25 & 10.10 & 0.99 \\
\hline Physical education and coaching & 13.37 & 0.61 & 13.39 & 0.99 & 16.84 & 2.36 \\
\hline Pre-school/early childhood education & 6.11 & 0.69 & 6.51 & 0.68 & 10.22 & 1.67 \\
\hline Secondary teacher education & 16.20 & 0.77 & 16.35 & 1.12 & 16.92 & $1.7 €$ \\
\hline
\end{tabular}




\begin{tabular}{lrrrrrr} 
Computer teacher education & 7.81 & 1.91 & 6.86 & 1.26 & 7.54 & 1.61 \\
Mathematics teacher education & 5.63 & 0.55 & 3.92 & 0.38 & 3.69 & 0.35 \\
Science teacher education & 10.11 & 1.26 & 10.01 & 1.54 & 7.66 & 1.14 \\
Social science teacher education & 11.89 & 1.06 & 9.32 & 1.15 & 12.38 & 1.41 \\
Special education & 3.85 & 0.24 & 4.00 & 0.33 & 7.93 & 1.36 \\
Other education & 18.89 & 0.68 & 14.76 & 0.79 & 18.29 & 1.97 \\
\multicolumn{1}{c}{ Arts \& Humanities } & & & & & & \\
Other philosophy, religion, theology & 9.76 & 0.60 & 13.33 & 1.06 & 24.18 & 2.80 \\
English Language, literature and letters & 22.43 & 0.56 & 21.97 & 0.71 & 23.93 & 1.85 \\
Other foreign languages and literature & 22.42 & 0.99 & 18.77 & 1.15 & 27.82 & 2.37 \\
Liberal Arts/General Studies & 27.83 & 1.21 & 34.90 & 1.69 & 31.20 & 2.56 \\
History, other & 23.32 & 0.78 & 25.27 & 1.03 & 23.23 & 1.98 \\
Dramatic arts & 15.57 & 1.49 & 18.39 & 1.95 & 16.09 & 3.11 \\
Fine arts, all fields & 16.62 & 0.86 & 17.90 & 1.13 & 19.94 & 2.04 \\
Music, all fields & 18.65 & 0.80 & 13.64 & 0.85 & 13.69 & 2.29 \\
Other visual and performing arts & 9.23 & 0.88 & 9.72 & 0.99 & 15.06 & 2.17 \\
$\quad$ Other Majors & & & & & & \\
Communications, general & 16.62 & 0.90 & 21.48 & 1.16 & 24.76 & 2.17 \\
Journalism & 8.13 & 0.53 & 12.82 & 1.20 & 16.42 & 2.47 \\
Other communications & 16.68 & 1.04 & 18.31 & 1.46 & 17.23 & 2.22 \\
Other natural resources and conservation & 13.98 & 1.40 & 13.11 & 1.84 & 11.85 & 2.01 \\
Home Economics & 22.96 & 0.92 & 28.01 & 1.79 & 16.84 & 2.39 \\
Law/Prelaw/Legal Studies & 7.30 & 0.79 & 11.88 & 1.76 & 7.82 & 1.29 \\
Library Science & 4.83 & 1.20 & 4.37 & 1.38 & 6.00 & 0.00 \\
Parks, Recreation, Leisure, and Fitness Studies & 19.33 & 1.37 & 25.56 & 2.18 & 20.36 & 3.01 \\
Public administration & 11.11 & 1.46 & 18.23 & 2.42 & 8.53 & 2.06 \\
Other public affairs & 11.00 & 1.73 & 12.18 & 2.67 & 13.12 & 3.26 \\
Other FIELDS & 21.53 & 1.67 & 29.93 & 2.66 & 28.23 & 3.91
\end{tabular}


Appendix Table A2

Occupational Distinctiveness by College Major

$\underline{1993}$

$\underline{2003}$

$\underline{2010}$

\begin{tabular}{|c|c|c|c|c|c|c|}
\hline Mathematics and Sciences & $\underline{\mathrm{OD}}$ & $\underline{\text { St Err }}$ & $\underline{\mathrm{OD}}$ & $\underline{\text { St Err }}$ & $\underline{\mathrm{OD}}$ & $\underline{\text { St Err }}$ \\
\hline Computer and information sciences & 0.707 & 0.017 & 0.656 & 0.018 & 0.520 & 0.018 \\
\hline Computer science & 0.763 & 0.008 & 0.693 & 0.008 & 0.577 & 0.010 \\
\hline Computer systems analysis & 0.727 & 0.027 & 0.727 & 0.030 & 0.609 & 0.034 \\
\hline Information services and systems & 0.719 & 0.021 & 0.612 & 0.017 & 0.501 & 0.014 \\
\hline Other computer and information sciences & 0.625 & 0.042 & 0.505 & 0.030 & 0.511 & 0.033 \\
\hline Applied mathematics & 0.505 & 0.023 & 0.506 & 0.020 & 0.419 & 0.028 \\
\hline Mathematics, general & 0.481 & 0.010 & 0.485 & 0.011 & 0.455 & 0.011 \\
\hline Operations research & 0.593 & 0.039 & 0.561 & 0.029 & 0.587 & 0.039 \\
\hline Statistics & 0.568 & 0.037 & 0.615 & 0.032 & 0.571 & 0.031 \\
\hline Other mathematics & 0.514 & 0.027 & 0.579 & 0.043 & 0.598 & 0.047 \\
\hline Animal sciences & 0.456 & 0.021 & 0.474 & 0.027 & 0.469 & 0.022 \\
\hline Food sciences and technology & 0.531 & 0.029 & 0.565 & 0.041 & 0.511 & 0.028 \\
\hline Plant sciences & 0.534 & 0.025 & 0.571 & 0.028 & 0.542 & 0.025 \\
\hline Other agricultural sciences & 0.509 & 0.027 & 0.489 & 0.038 & 0.540 & 0.028 \\
\hline Biochemistry and biophysics & 0.624 & 0.019 & 0.606 & 0.020 & 0.481 & 0.020 \\
\hline Biology, general & 0.549 & 0.007 & 0.550 & 0.008 & 0.423 & 0.009 \\
\hline Botany & 0.519 & 0.036 & 0.517 & 0.041 & 0.581 & 0.038 \\
\hline Cell and molecular biology & 0.634 & 0.037 & 0.656 & 0.032 & 0.612 & 0.029 \\
\hline Ecology & 0.540 & 0.039 & 0.553 & 0.037 & 0.572 & 0.031 \\
\hline Genetics, animal and plant & 0.736 & 0.054 & 0.679 & 0.039 & 0.564 & 0.045 \\
\hline Microbiological sciences and immunology & 0.625 & 0.019 & 0.545 & 0.022 & 0.492 & 0.023 \\
\hline Nutritional sciences & 0.563 & 0.024 & 0.537 & 0.040 & 0.528 & 0.032 \\
\hline Pharmacology, human and animal & 0.732 & 0.044 & 0.689 & 0.053 & 0.637 & 0.036 \\
\hline Physiology and pathology, human and animal & 0.563 & 0.044 & 0.511 & 0.040 & 0.481 & 0.040 \\
\hline Zoology, general & 0.567 & 0.017 & 0.520 & 0.022 & 0.427 & 0.025 \\
\hline Other biological sciences & 0.518 & 0.021 & 0.572 & 0.025 & 0.510 & 0.027 \\
\hline Environmental science or studies & 0.500 & 0.032 & 0.497 & 0.030 & 0.467 & 0.022 \\
\hline Forestry sciences & 0.564 & 0.022 & 0.634 & 0.028 & 0.545 & 0.029 \\
\hline Chemistry, except biochemistry & 0.540 & 0.008 & 0.531 & 0.010 & 0.511 & 0.010 \\
\hline Atmospheric sciences and meteorology & 0.702 & 0.037 & 0.680 & 0.036 & 0.691 & 0.032 \\
\hline Earth sciences & 0.532 & 0.044 & 0.618 & 0.024 & 0.513 & 0.029 \\
\hline Geology & 0.610 & 0.016 & 0.598 & 0.020 & 0.620 & 0.018 \\
\hline Other Geological sciences, & 0.695 & 0.041 & 0.729 & 0.039 & 0.691 & 0.042 \\
\hline Oceanography & 0.631 & 0.044 & 0.613 & 0.060 & 0.652 & 0.056 \\
\hline Astronomy and astrophysics & 0.801 & 0.034 & 0.676 & 0.058 & 0.583 & 0.044 \\
\hline Physics & 0.516 & 0.011 & 0.509 & 0.012 & 0.416 & 0.014 \\
\hline Other physical sciences & 0.346 & 0.029 & 0.386 & 0.039 & 0.352 & 0.038 \\
\hline
\end{tabular}




\section{Social Sciences}

Agricultural economics

Economics

Public policy studies

International relations

Political science and government

Educational psychology

Clinical psychology

Counseling psychology

Experimental psychology

General psychology

Industrial/Organizational psychology

Social psychology

Other psychology

Anthropology and archaeology

Criminology

Sociology

Area and Ethnic Studies

Linguistics

Philosophy of science

Geography

History of science

Other social sciences

Engineering

Aerospace \& related engineering

Chemical engineering

Architectural engineering

Civil engineering

Computer and systems engineering

Electrical \& related engineering

Industrial and manufacturing engineering

Mechanical engineering

Agricultural engineering

Bioengineering and biomedical engineering

Engineering sciences, mechanics and physics

Environmental engineering

Engineering, general

Geophysical and geological engineering

Materials engineering (inc. ceramics \& textiles)

Metallurgical engineering

Mining and minerals engineering

Naval architecture and marine engineering

Nuclear engineering

Petroleum engineering

$\begin{array}{llllll}0.444 & 0.023 & 0.559 & 0.027 & 0.568 & 0.024 \\ 0.410 & 0.008 & 0.408 & 0.010 & 0.466 & 0.008 \\ 0.728 & 0.001 & 0.668 & 0.042 & 0.617 & 0.038 \\ 0.442 & 0.024 & 0.437 & 0.024 & 0.463 & 0.020 \\ 0.392 & 0.008 & 0.433 & 0.010 & 0.457 & 0.007 \\ 0.419 & 0.031 & 0.496 & 0.035 & 0.550 & 0.036 \\ 0.461 & 0.025 & 0.531 & 0.024 & 0.459 & 0.027 \\ 0.488 & 0.025 & 0.506 & 0.029 & 0.517 & 0.022 \\ 0.396 & 0.025 & 0.444 & 0.031 & 0.395 & 0.032 \\ 0.338 & 0.008 & 0.386 & 0.010 & 0.413 & 0.008 \\ 0.458 & 0.027 & 0.502 & 0.041 & 0.492 & 0.031 \\ 0.495 & 0.026 & 0.448 & 0.036 & 0.419 & 0.025 \\ 0.395 & 0.017 & 0.437 & 0.028 & 0.410 & 0.027 \\ 0.352 & 0.023 & 0.372 & 0.024 & 0.422 & 0.020 \\ 0.497 & 0.032 & 0.521 & 0.039 & 0.542 & 0.029 \\ 0.381 & 0.008 & 0.368 & 0.012 & 0.412 & 0.009 \\ 0.346 & 0.027 & 0.393 & 0.027 & 0.463 & 0.019 \\ 0.427 & 0.036 & 0.544 & 0.039 & 0.509 & 0.039 \\ 0.426 & 0.038 & 0.479 & 0.039 & 0.463 & 0.016 \\ 0.382 & 0.020 & 0.371 & 0.027 & 0.355 & 0.022 \\ 0.501 & 0.022 & 0.486 & 0.042 & 0.612 & 0.059 \\ 0.349 & 0.014 & 0.387 & 0.023 & 0.430 & 0.017\end{array}$

$\begin{array}{llllll}0.590 & 0.017 & 0.563 & 0.019 & 0.525 & 0.023\end{array}$

$\begin{array}{llllll}0.585 & 0.011 & 0.563 & 0.014 & 0.537 & 0.011\end{array}$

$\begin{array}{lllllll}0.704 & 0.022 & 0.669 & 0.028 & 0.604 & 0.024\end{array}$

$\begin{array}{llllll}0.703 & 0.007 & 0.716 & 0.008 & 0.682 & 0.009\end{array}$

$\begin{array}{llllll}0.733 & 0.017 & 0.683 & 0.014 & 0.550 & 0.016\end{array}$

$\begin{array}{lllllll}0.667 & 0.006 & 0.624 & 0.007 & 0.589 & 0.006\end{array}$

$\begin{array}{llllll}0.504 & 0.015 & 0.469 & 0.016 & 0.466 & 0.015\end{array}$

$\begin{array}{llllll}0.635 & 0.006 & 0.605 & 0.007 & 0.575 & 0.008\end{array}$

$\begin{array}{llllll}0.603 & 0.035 & 0.581 & 0.033 & 0.523 & 0.032\end{array}$

$\begin{array}{llllll}0.684 & 0.046 & 0.630 & 0.039 & 0.513 & 0.034\end{array}$

$\begin{array}{llllll}0.529 & 0.019 & 0.537 & 0.030 & 0.427 & 0.026\end{array}$

$\begin{array}{llllll}0.664 & 0.041 & 0.661 & 0.033 & 0.597 & 0.030\end{array}$

$\begin{array}{llllll}0.477 & 0.023 & 0.474 & 0.027 & 0.464 & 0.029\end{array}$

$\begin{array}{llllll}0.813 & 0.070 & 0.789 & 0.039 & 0.717 & 0.031\end{array}$

$\begin{array}{llllll}0.613 & 0.027 & 0.571 & 0.032 & 0.517 & 0.029\end{array}$

$\begin{array}{llllll}0.663 & 0.029 & 0.656 & 0.027 & 0.600 & 0.035\end{array}$

$\begin{array}{llllll}0.678 & 0.032 & 0.698 & 0.039 & 0.651 & 0.042\end{array}$

$\begin{array}{llllll}0.632 & 0.023 & 0.613 & 0.042 & 0.600 & 0.033\end{array}$

$\begin{array}{llllll}0.723 & 0.036 & 0.707 & 0.043 & 0.631 & 0.041\end{array}$

$\begin{array}{lllllll}0.739 & 0.029 & 0.659 & 0.040 & 0.669 & 0.038\end{array}$ 


\begin{tabular}{|c|c|c|c|c|c|c|}
\hline Other engineering & 0.492 & 0.021 & 0.476 & 0.030 & 0.430 & 0.031 \\
\hline \multicolumn{7}{|l|}{ Health Related Majors } \\
\hline Audiology and speech pathology & 0.584 & 0.023 & 0.571 & 0.026 & 0.643 & 0.021 \\
\hline Health services administration & 0.533 & 0.031 & 0.573 & 0.026 & 0.444 & 0.020 \\
\hline Health/medical assistants & 0.749 & 0.050 & 0.858 & 0.001 & 0.692 & 0.052 \\
\hline Health/medical technologies & 0.708 & 0.014 & 0.656 & 0.020 & 0.579 & 0.024 \\
\hline Medical preparatory programs (pre-med, etc.) & 0.817 & 0.010 & 0.741 & 0.018 & 0.604 & 0.028 \\
\hline Medicine & 0.776 & 0.017 & 0.759 & 0.019 & 0.661 & 0.027 \\
\hline Nursing & 0.780 & 0.008 & 0.764 & 0.010 & 0.709 & 0.010 \\
\hline Pharmacy & 0.721 & 0.015 & 0.759 & 0.015 & 0.597 & 0.024 \\
\hline Physical therapy and other rehabilitation & 0.651 & 0.021 & 0.635 & 0.024 & 0.566 & 0.021 \\
\hline Public health incl. epidemiology & 0.550 & 0.035 & 0.428 & 0.036 & 0.436 & 0.034 \\
\hline Other health/medical sciences & 0.573 & 0.020 & 0.562 & 0.023 & 0.508 & 0.023 \\
\hline \multicolumn{7}{|l|}{ Technology } \\
\hline Computer programming & 0.686 & 0.022 & 0.701 & 0.023 & 0.608 & 0.030 \\
\hline Data processing & 0.736 & 0.038 & 0.651 & 0.028 & 0.696 & 0.002 \\
\hline Electrical and electronic technologies & 0.621 & 0.014 & 0.589 & 0.022 & 0.545 & 0.025 \\
\hline Industrial production technologies & 0.460 & 0.018 & 0.476 & 0.025 & 0.442 & 0.025 \\
\hline Mechanical engineering-related technologies & 0.574 & 0.017 & 0.546 & 0.030 & 0.575 & 0.029 \\
\hline Other engineering-related technologies & 0.475 & 0.023 & 0.456 & 0.024 & 0.411 & 0.024 \\
\hline Architecture/Environmental Design & 0.659 & 0.013 & 0.599 & 0.015 & 0.524 & 0.015 \\
\hline \multicolumn{7}{|l|}{$\underline{\text { Business }}$} \\
\hline Actuarial science & 0.730 & 0.059 & 0.681 & 0.068 & 0.642 & 0.038 \\
\hline Other agricultural business and production & 0.487 & 0.030 & 0.506 & 0.028 & 0.644 & 0.049 \\
\hline Accounting & 0.573 & 0.006 & 0.536 & 0.008 & 0.478 & 0.016 \\
\hline Business administration and management & 0.434 & 0.005 & 0.429 & 0.006 & 0.368 & 0.012 \\
\hline Business, general & 0.390 & 0.008 & 0.391 & 0.011 & 0.371 & 0.018 \\
\hline Business and managerial economics & 0.437 & 0.012 & 0.429 & 0.018 & 0.493 & 0.020 \\
\hline Financial management & 0.488 & 0.010 & 0.460 & 0.012 & 0.443 & 0.022 \\
\hline Other business management/administration & 0.390 & 0.010 & 0.402 & 0.013 & 0.405 & 0.020 \\
\hline Business marketing/marketing management & 0.478 & 0.008 & 0.487 & 0.011 & 0.432 & 0.018 \\
\hline Marketing research & 0.461 & 0.020 & 0.504 & 0.031 & 0.644 & 0.054 \\
\hline \multicolumn{7}{|l|}{ Education } \\
\hline Computer teacher education & 0.773 & 0.001 & 0.771 & 0.001 & 0.761 & 0.002 \\
\hline Mathematics teacher education & 0.540 & 0.022 & 0.601 & 0.023 & 0.688 & 0.022 \\
\hline Science teacher education & 0.421 & 0.024 & 0.469 & 0.030 & 0.494 & 0.031 \\
\hline Social science teacher education & 0.444 & 0.019 & 0.533 & 0.024 & 0.571 & 0.022 \\
\hline
\end{tabular}




\begin{tabular}{|c|c|c|c|c|c|c|}
\hline Education administration & 0.584 & 0.031 & 0.485 & 0.038 & 0.703 & 0.044 \\
\hline Counselor education and guidance services & 0.621 & 0.042 & 0.747 & 0.047 & 0.791 & 0.002 \\
\hline Elementary teacher education & 0.595 & 0.006 & 0.589 & 0.008 & 0.579 & 0.017 \\
\hline Physical education and coaching & 0.434 & 0.009 & 0.492 & 0.016 & 0.508 & 0.027 \\
\hline Pre-school/kindergarten/early childhood & 0.562 & 0.027 & 0.633 & 0.025 & 0.665 & 0.031 \\
\hline Secondary teacher education & 0.373 & 0.011 & 0.427 & 0.013 & 0.496 & 0.024 \\
\hline Special education & 0.629 & 0.016 & 0.633 & 0.020 & 0.631 & 0.038 \\
\hline Other education & 0.376 & 0.009 & 0.455 & 0.012 & 0.529 & 0.026 \\
\hline \multicolumn{7}{|l|}{$\underline{\text { Arts, Humanities }}$} \\
\hline English Language, literature and letters & 0.360 & 0.008 & 0.405 & 0.010 & 0.426 & 0.019 \\
\hline Other foreign languages and literature & 0.335 & 0.012 & 0.407 & 0.015 & 0.398 & 0.024 \\
\hline Liberal Arts/General Studies & 0.264 & 0.012 & 0.287 & 0.017 & 0.268 & 0.020 \\
\hline History, other & 0.321 & 0.008 & 0.364 & 0.011 & 0.410 & 0.020 \\
\hline Dramatic arts & 0.438 & 0.022 & 0.472 & 0.025 & 0.590 & 0.040 \\
\hline Fine arts, all fields & 0.432 & 0.011 & 0.454 & 0.014 & 0.462 & 0.026 \\
\hline Music, all fields & 0.427 & 0.014 & 0.524 & 0.017 & 0.457 & 0.034 \\
\hline Other visual and performing arts & 0.508 & 0.018 & 0.489 & 0.019 & 0.489 & 0.032 \\
\hline \multicolumn{7}{|l|}{ Other Majors } \\
\hline Communications, general & 0.420 & 0.012 & 0.375 & 0.015 & 0.390 & 0.024 \\
\hline Journalism & 0.462 & 0.013 & 0.433 & 0.019 & 0.475 & 0.034 \\
\hline Other communications & 0.393 & 0.017 & 0.423 & 0.020 & 0.457 & 0.028 \\
\hline Other natural resources and conservation & 0.583 & 0.028 & 0.616 & 0.033 & 0.628 & 0.042 \\
\hline Home Economics & 0.432 & 0.012 & 0.397 & 0.017 & 0.467 & 0.029 \\
\hline Law/Prelaw/Legal Studies & 0.492 & 0.023 & 0.450 & 0.028 & 0.536 & 0.025 \\
\hline Library Science & 0.682 & 0.040 & 0.736 & 0.062 & 0.900 & 0.001 \\
\hline Parks, Recreation, Leisure, and Fitness Studies & 0.366 & 0.014 & 0.405 & 0.024 & 0.489 & 0.032 \\
\hline Public administration & 0.473 & 0.026 & 0.466 & 0.034 & 0.682 & 0.046 \\
\hline Other public affairs & 0.668 & 0.001 & 0.593 & 0.041 & 0.646 & 0.062 \\
\hline Other philosophy, religion, theology & 0.408 & 0.013 & 0.420 & 0.016 & 0.406 & 0.028 \\
\hline Social Work & 0.585 & 0.012 & 0.592 & 0.016 & 0.559 & 0.023 \\
\hline Other fields not elsewhere listed & 0.317 & 0.019 & 0.345 & 0.025 & 0.389 & 0.040 \\
\hline
\end{tabular}


Appendix B

Harmonization of Occupations Across Waves of

The National Survey of College Graduates

\begin{tabular}{|c|c|}
\hline $\begin{array}{l}\text { Because } \\
\text { Graduate } \\
\text { fields) in } \\
\text { are the cl }\end{array}$ & $\begin{array}{l}\text { ew occupations were added to later waves of the National Survey of College } \\
\text {, and because some older occupations were eliminated (or aggregated with similar } \\
\text { arlier waves, it was necessary for us to harmonize the occupation definition. These } \\
\text { anges that we implemented: }\end{array}$ \\
\hline $\begin{array}{l}\text { The follo } \\
\text { science o }\end{array}$ & $\begin{array}{l}\text { ing occupations were combined into code } 110610 \text { "Other computer information } \\
\text { cupations:" }\end{array}$ \\
\hline From 201 & \\
\hline Code & Description \\
\hline 110570 & Information security analysts \\
\hline 110610 & OTHER computer information science occupations \\
\hline 110560 & Database administrators \\
\hline 110580 & Network and computer systems administrators \\
\hline 110520 & Computer network architect \\
\hline 110590 & Software developers - applications and systems software \\
\hline 110600 & Web developers \\
\hline 110510 & Computer \& information scientists, research \\
\hline From 200 & \\
\hline 110580 & OTHER computer information science occupations \\
\hline 110550 & Database administrators \\
\hline 110560 & Network and computer systems administrators \\
\hline 110570 & Network systems and data communications analysts \\
\hline 110510 & Computer and information scientists, research \\
\hline From 199 & \\
\hline 110540 & Information Systems Scientists and Analysts \\
\hline 110550 & OTHER Computer and Information Science Occupations \\
\hline
\end{tabular}

\begin{tabular}{|l|c|}
\hline \multicolumn{2}{|c|}{ The following occupations that appeared in the 1993 wave NSCG were combined into code } \\
742990 "Postsecondary Teachers: Other" which appears in the 2003 and 2010 waves \\
\hline Codes & Description \\
\hline 632840 & \\
Through & Postsecondary Teachers (in various listed fields) \\
642990 & \\
\hline
\end{tabular}




\begin{tabular}{|c|l|}
\hline \multicolumn{2}{|l|}{ The following occupations merged to form the broad occupation of “Management" } \\
\hline From 2003 and 2010 surveys: \\
\hline Codes & \\
\hline 711410 & Top-level managers, executives, administrators \\
\hline 621420 & Computer and information systems managers \\
\hline 621430 & Engineering managers \\
\hline 621440 & Medical and health services managers \\
\hline 621450 & Natural sciences managers \\
\hline 711460 & Education administrators (e.g. registrar, dean, principal) \\
\hline 711470 & OTHER mid-level managers \\
\hline \\
From 1993 Survey: \\
\hline 611410 & Top and Mid-Level Managers, Executives, Administrators \\
\hline
\end{tabular}




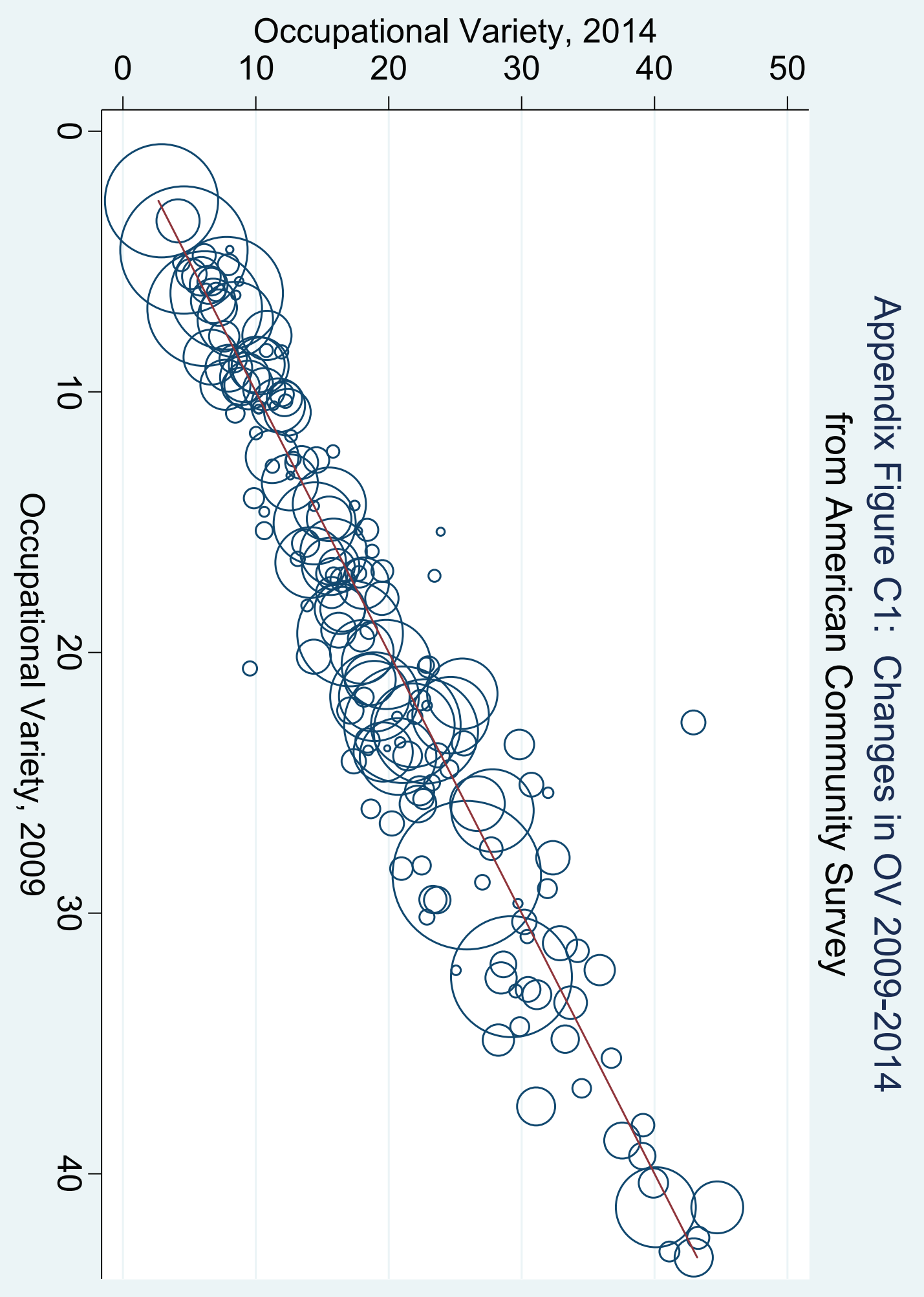

